\title{
TV/Series
}

12| 2017

Littérature et séries télévisées/Literature and TV series

\section{Light Shadows: Loose Adaptations of Gothic Literature in American TV Series of the 1960s and early 1970 s}

Dennis Tredy

CpenEdition

Journals

Electronic version

URL: http://journals.openedition.org/tvseries/2200

DOI: $10.4000 /$ tvseries.2200

ISSN: 2266-0909

Publisher

GRIC - Groupe de recherche Identités et Cultures

Electronic reference

Dennis Tredy, «Light Shadows: Loose Adaptations of Gothic Literature in American TV Series of the 1960s and early 1970s », TV/Series [Online], 12 | 2017, Online since 20 September 2017, connection on 01 May 2019. URL : http://journals.openedition.org/tvseries/2200 ; DOI : 10.4000/tvseries.2200

This text was automatically generated on 1 May 2019.

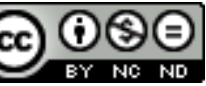

TV/Series est mis à disposition selon les termes de la licence Creative Commons Attribution - Pas d'Utilisation Commerciale - Pas de Modification 4.0 International. 


\title{
Light Shadows: Loose Adaptations of Gothic Literature in American TV Series of the 1960s and early 1970s
}

\author{
Dennis Tredy
}

1 In the late 1960 's and early 1970 's, in a somewhat failed attempt to wrestle some high ratings away from the network leader $\mathrm{CBS}, \mathrm{ABC}$ would produce a spate of supernatural sitcoms, soap operas and investigative dramas, adapting and borrowing heavily from major works of Gothic literature of the nineteenth and early twentieth century. The trend began in 1964, when ABC produced the sitcom The Addams Family (1964-66), based on works of cartoonist Charles Addams, and CBS countered with its own The Munsters (CBS, 1964-66) -both satirical inversions of the American ideal sitcom family in which various monsters and freaks from Gothic literature and classic horror films form a family of misfits that somehow thrive in middle-class, suburban America. Then came ABC's unexpected afternoon 'Gothic soap opera', written and produced by Dan Curtis, television's heir apparent to Roger Corman and his spate of Victorian-style B-movie adaptations of the works of Edgar Allan Poe in the early 1960's. Curtis would not only give us a string of made-for TV movies during the period (including his critically acclaimed Dracula and The Turn of the Screw), but also Dark Shadows (ABC, 1966-71), a daily soap opera that ran for a staggering 1,225 episodes and that directly borrowed famous characters and story-lines from landmark works of Gothic literature. By the early seventies, Curtis and $A B C$ went one step further, as such legendary Gothic creatures would be among the many perpetrators of paranormal crimes investigated by the Colombo-like investigative reporter, Carl Kolchak (Darren McGavin), in the now-cult series Kolchak: The Night Stalker (1974-75).

2 This study aims to take a much closer look at these four series, all of which were launched as unexpected hybrids, as they successively sought to combine landmark characters and storylines from Gothic literature and occasionally science fiction with three otherwise conventional TV formats -first with the family sitcom in the mid-1960s, then with the 
daytime soap opera in the late 1960s, and finally with the nighttime crime drama in the early 1970s. As Helen Wheatley has argued, it seems that all Gothic TV programs are hybrids of some sort (8), and these three experiments clearly support that claim. In terms of adaptation and 'fidelity', the borrowing from literary source texts was done in very broad strokes, often relying more on previous low-brow adaptations of the Gothic literary source or the rather summary or diffuse versions of the original stories that have become part of our collective consciousness. However, it would be a rush to judgement to write these experimental series off as nothing more than the cheap borrowing of popular horror icons that often, even when the goal was not comedy, seemed to slip into the realm of burlesque parody. Is it possible that they were in fact a clever and somewhat underhanded way of questioning conservative family values, or showing some darker side to America's idealized vision of itself? Was there anything subversive, hard-hitting or ground-breaking partially veiled by the melodramatic dialogues of the early Gothic soap, the canned laughter of the Gothic sitcom or the low-budget special effects of the first paranormal investigation series? In order to better understand the impact these programs had, one must also understand the rather tranquil and extremely conventional television landscape that would be disrupted by the raucous intrusion of these monstermashes-and key part of that landscape would also be the ongoing battle for ratings between the networks for the 'new format' that would grab the top spot in Nielsen ratings. Indeed, the creation of all three of these new subgenres is inextricably connected to the famed 'Network Wars' that were raging (and indeed still rage) between the top networks, though in this case the battle was more specifically between feisty but lowbudget $\mathrm{ABC}$, the perennial third-place finisher, and the reigning champ $\mathrm{CBS}$, the toprated network since $\mathrm{CBS}$ founder William Paley made popular programming his priority in the early 1950s. Why did ABC in particular think that these new hybrids were the winning combination, and who was their target audience? Even more importantly, one wonders why they failed to reach that audience at the time and garner the higher ratings they so coveted -for most of these experiments, with the exception of Dark Shadows, were short-lived, fading after a season or two due to disappointing ratings -and none of them propelled $\mathrm{ABC}$ to that much-desired victory over rival CBS. Yet, one of the great paradoxes of these shows is that 'failure' at the time of broadcast did not mean the end of the program's popularity -quite the contrary. For their popularity would grow exponentially among future generations through syndicated reruns, eventually achieving cult status and making these unusual TV icons (Morticia Addams, Hermann Munster, Barnabas Collins and Carl Kolchak -just to name a few) household names today. More importantly, these supposedly failed experimental formats would all eventually catch on, particularly in the last twenty years, when networks and especially cable channels finally brought in big-budget production values and more elaborate or what some might call 'cinematic' treatment of the subject-matter. Many of the most popular programs of recent years -including FOX's X-Files (FOX 1993-2002; 2016) and Fringe (2008-13), Showtime's Penny Dreadful (2014-2016), HBO's True Blood (2008-14) and even, for young children, Nickelodeon's immensely popular Monster High (2010-present) -all owe a great deal to their direct lineage back to these early experiments in popular television -and all of this would initially grow out of the quite blandly conventional television landscape of the early sixties. 


\section{Black and (Decidedly) White TV: The Television Landscape of the 1960s}

3 In order to better understand how this new 'light Gothic' subgenre came about, one must take into account the general TV landscape of the early 1960s that would give rise to it. In terms of the sitcom, if the 1950's had been a decade of topical, irreverent and often politically incorrect sitcoms (I Love Lucy, The Honeymooners, The Phil Silvers Show) and ethnically diverse sitcoms (The Goldbergs, I Remember Mama, Amos n' Andy, Beulah) -all direct adaptations of popular radio shows of the 1940s. By 1960, however, the sitcom landscape had become surprisingly white, middle-class and conservative on all networks, and particular on ratings leader CBS. The toning down and 'whitewashing' of the comedy landscape came about for many reasons. With fewer and fewer hit radio programs from the 1940s left to transpose to television, new programs were often made from scratch and naturally reflected far more their own time, the notoriously conservative 1950s. The single biggest factor in this shift, though, was clearly the full expansion of the television audience nationally, from the exclusively urban audiences of the Northeast in the early 1950s to the suburbs and then every corner rural America by the end of the decade. Newly elected CBS President James Aubrey (1959-65) was simply following the mantra of the network's founder, William Paley, the notion that American families enjoy seeing a reflection of themselves in their sitcoms, and that the station's target audience had to be "the heavy viewing center" -that is, the largest demographic, which by 1960 had become largely rural, conservative and less educated than that of TV's early years, and was often condescendingly referred to as "Bill and Mary Six-Pack" (Jones 164). It was this demographic shift and the overriding conservativism and conformism of the 1950s that would push all networks to shy away from ethnic humor and end their contracts with once-popular Jewish and African American comedians, a move toward all-WASP sitcom casts that was compounded by the networks' fear of reiterating certain public scandals that had befallen the Ethnicoms of the 1950s (e.g., the arrest of a leading cast member on The Goldbergs as a Communist sympathizer or the vocal NAACP protests over CBS's decision to adapt Amos n' Andy for television). By the early 1960s, it was thus safer and more in line with the new national demographic to provide comparatively bland 'family sitcoms' that either focused on tame if not ideal WASP suburban life or took us even deeper into the heartland with programs focusing on simple but honest country folk. The more suburban fare, often referred to in the industry as the WASPcom, included longrunning favorites The Adventures of Ozzie and Harriet (ABC, 1952-66, 425 ep.), Father Knows Best (CBS/NBC, 1954-60, 203 ep.), Leave It to Beaver (CBS/ABC, 1957-63, 234 ep.) and Dennis the Menace (CBS 1959-63, 146 ep.). If CBS was leading the field in the suburban sitcom, they were also the only network to invest heavily in the rural sitcom, with the two most popular shows of the early sixties: The Andy Griffith Show (1960-68, 249 ep.) and The Beverly Hillbillies (1962-71, 274 ep.). This 'endearing country bumpkin' trend would become a ratings magnet, and spin-offs and lookalikes would spring up later in the decade, including the later number-one series Gomer Pyle USMC (1964-70, 150 ep.) -a spin-off of The Andy Griffith Show -as well as hits like Petticoat Junction (1963-70, 222 ep.), its spin-off Green Acres (1965-71, 170 ep.), and the rural variety show Hee-Haw (1969-71, 51 ep.). One might indeed wonder how irreverent parodies of Gothic literature could ever emerge in such a tranquil if not pastoral TV landscape. 
In fact, the change would come through eternal third-place ABC's attempt to somehow climb in the ratings by focusing their resources on "counterprogramming" that they hoped would please the target audience they had chosen for themselves in 1952, when the flailing network was saved by a merger with Paramount Pictures. Their target was younger viewers, in the hopes that by drawing in the children and teens those same young people would draw in their parents. Thus Aubrey's rival at ABC, Ollie Treiz, decided to provide entertainment focused on young adults and even children in their primetime line-up (Goldenson \& Wolf, 251). ABC thus seems to have opted for three different types of comedy programs in this new move, two of which would in fact be loose adaptations of popular shows of the 1950s. The first salvo, in 1961, was the creation of primetime cartoon programs that brought back the irreverent humor and story-lines of the sitcoms of the 1950s but packaged them for children, though clearly hoping parents would also get hooked on the obvious similarities to their old fifties favorites. As Gerard Jones puts it, it was "the growing importance of children in ratings [that] allowed the more dangerous spirits of 1950's TV" to seep back into primetime, but "in compromised and more juvenile forms" (169). Most notable among these were the network's four leading Hanna-Barbara cartoons: Top Cat (1961-62, 30 ep.), in which the military-based Phil Silvers Show was transposed into a group of lazy alley cats, with a voice impersonation of Phil Silvers for the main character and several other stars of the earlier sitcom actually providing the voices for other cats; The Flintstones (1960-66, $166 \mathrm{ep}$.), which though set in prehistoric times was a carbon copy of Jackie Gleason's The Honeymooners, right down to the voice characterizations and often identical story-lines; The Jetsons (1962-63, 24 ep.), the first $\mathrm{ABC}$ program to be shown in color and itself a futuristic remake of The Flintstones and the many 'bumbling dad' sitcoms of the 1950s; and the short-lived gamble of Calvin \& the Colonel (1961-62, $28 \mathrm{ep}$.), in which the story-lines and humor of Amos n' Andy were stripped of their racial element as it was now simply about a southern-accented fox and a bear -though the characters were still voiced by the actual stars of the long-running and controversially ethnic (if not racist) radio show, Gosden and Correll.

The second type of new ABC comedy, launched in 1962, was quite similar, though not as specifically child-oriented. It was the renewal of the military sitcom, a subgenre that had been made popular by the above-mentioned Sgt. Bilko of The Phil Silvers Show of the late 1950s. However, while Silvers's Bilko more openly mocked authority, delivered politically incorrect zingers and had a diverse cast, the lookalikes provided by $A B C$ in the first half of the 1960s were pure escapism and far more conservative -and though, unlike Bilko, they were set during wartime, all three focused on outposts that were so far removed from the action that they had plenty of time for dim-witted and slap-stick shenanigans. In this group we find McHale's Navy (1962-66), which was clearly a watered-down version of The Phil Silvers Show set at sea, so much so that the same producer, Edward J. Montagne, and certain writers of the earlier show were picked up for it by $A B C$ and the working title at ABC was even Bilko Joins the Navy ("McHale's Navy", Archive...). This was quickly followed by a second Bilko lookalike, Broadside (1964-65), which gave us a female Bilko character as the comedy was centered on a group of female auto mechanics assigned to an all-male naval base in the Pacific, a short-lived series that was quickly followed by F-Troop (1965-66), set this time not in a remote Navy camp far from the action of World War II but in an even more remote army camp during the American Civil War, an outpost that similarly saw no action and left plenty of time for Bilkoesque antics and get-rich-quick schemes. Though only McHale's Navy was successful at the time, F-Troop would become a 
favorite among children and young adults in syndication, and all three opened the door to far more serious and hard-hitting versions of the military sitcom by the 1970s and the arrival of long-running $M^{*} A^{*} S^{*} H$ on CBS (1972-83) ${ }^{1}$.

However, after focusing on irreverent cartoons and tame military sitcoms, it was the third type of 'counterprogramming' by $\mathrm{ABC}$ that would end up bringing loosely adapted Gothic literature to the small screen in a most surprising way. It was in fact a trend that CBS had started in 1961 when it first brought viewers the fantastic sitcom -a strange blend of suburban or rural settings into which characters with supernatural powers have been dropped, leading to all types of unexpected 'situations'. CBS's early successes in this subgenre included Mr. Ed (1961-65), the talking horse, and My Favorite Martian (1963-66), the story of how a small-town family deals with having a Martian with superpowers, played by Ray Waltson, posing as live-in 'Uncle Martin'. CBS president Aubrey, who had previously worked for $\mathrm{ABC}$ and knew the importance of young audiences, had created this new hybrid for CBS (Jones 168)-the idea apparently being that if suburban and rural sitcoms work for adults, they are too tame to appeal to kids, so why not spice things up by throwing into ideal small-town America a fantastic character? Though many were upset with these new "fantastical gimmick sitcoms" -often written off as 'Idiotcoms' and leading to the resignation of many big names at the network, including the mainline talk show host Jack Paar, who accused Aubrey of dumbing down the network in only three years and pandering to the lowest common denominator (Jones 164, 168) -the combination of WASPcoms, Ruralcoms and what David Marc would dub Magicoms (107) would ensure CBS's dominance in the early 1960s (e.g., 8 out of the 15 top shows in 1961-62, 14 out of 15 top shows in 1963-64, according to Nielsen ratings ${ }^{2}$ ). However, ABC's third type of new programming followed CBS's lead and even did one better, for $A B C$ would come up with a long-running series that was the top-rated sitcom and number-two program in 1964, Bewitched (1963-72), by imagining a pretty witch, Samantha Stevens, trying to pass for a 'normal' suburban housewife. This would start the first of several battles between the networks for the top spot through this new subgenre, for NBC would throw its hat into the ring with its own lookalike of Bewitched, I Dream of Jeannie (1964-1970), while CBS and ABC were working feverishly in secret on rival projects for 1964, two similar shows that the networks each thought would snag the top spot and be the ultimate fantastical/rural hybrid, for the two networks were about to introduce monsters from Gothic literature into quiet American suburbia...

\section{Perfectly (Ab)Normal American Families: The Gothic-Monsters-in-the-Suburbs Battle}

$7 \quad \mathrm{CBS}$ and $\mathrm{ABC}$ were thus both betting that the key to ratings success was to bring classic Gothic monsters into this mix of fantastical misfits -which for the moment included aliens, talking horses and automobiles, kind witches and sexy genies -who all somehow ended up living in quiet American suburbs in the sitcom world of the early 1960s and did their best to somehow 'fit in'. As Gerard Jones, points out, children in particular seemed to identify with the 'wacky misfits' and to enjoy the new genre (169), in part undoubtedly as the premise disrupted and seemed to mock the quiet and conservative worlds of their parent's favorite sitcoms (and possibly the real world they were being raised in). 
Thus, bringing in ghouls and monsters seemed like a logical next step, and viewership studies have long showed that children are naturally drawn to TV programs that find a way to bring in horror icons and tropes (Messenger-Davis, 164-65). At the time, however, network executives only had to notice the success of TV and film horror was already having with young audiences. For example, the two networks had already seen the appeal of the supernatural and mysterious dimension in TV drama, particularly in the hugely successful science-fiction anthology series of the late fifties and early sixties, including The Twilight Zone (CBS, 1959-64, 156 ep.), its lookalike for even younger audiences, Outer Limits (ABC 1963-65, 49 ep.) and the long-running adult favorite Alfred Hitchcock Presents (CBS 1955-60, 62-64: NBC 1960-62, 64-65, 360 ep.). In addition, by 1964, feature monster films had been all the rage at cinemas for nearly a decade, drawing in huge audiences of young people every week. This included the late-1950's popularity of a spate of Hammer Film horror features directed by Terrence Fisher and starring the likes of Peter Cushing and Christopher Lee, including the highly successful The Curse of Frankenstein (1957), Dracula (1958) and Brides of Dracula (1960). These British productions were followed closely by American B-movie producer Roger Corman's popular series of eight feature-length adaptations of the works of Edgar Allan Poe between 1960 and 1964, seven of which starred Vincent Price: House of Usher (1960), The Pit and the Pendulum (1961), Premature Burial (with Ray Milland) and Tales of Terror (1962), The Raven and Haunted Palace (1963), The Masque of the Red Death and The Tomb of Ligeia (1964). In addition, during this same period, young movie-goers were flocking to see re-releases of Universal's successful horror classics from the 1930s, starring Bela Lugosi as Frankenstein [Frankenstein (1931) and The Bride of Frankenstein (1935)], Boris Karloff as Dracula [Dracula (1931) and Dracula's Daughter (1936)] and Henry Hill as the Wolfman [Werewolf of London (1935)]. It was a veritable monster craze drawing young people to movie theatres in droves, so it seemed quite logical that bringing these creatures to television, in a hilarious new format that children also adored -that of the fantastic sitcom -would be surefire ratings magnet.

Plate 1 - Perfectly (ab)normal American families...

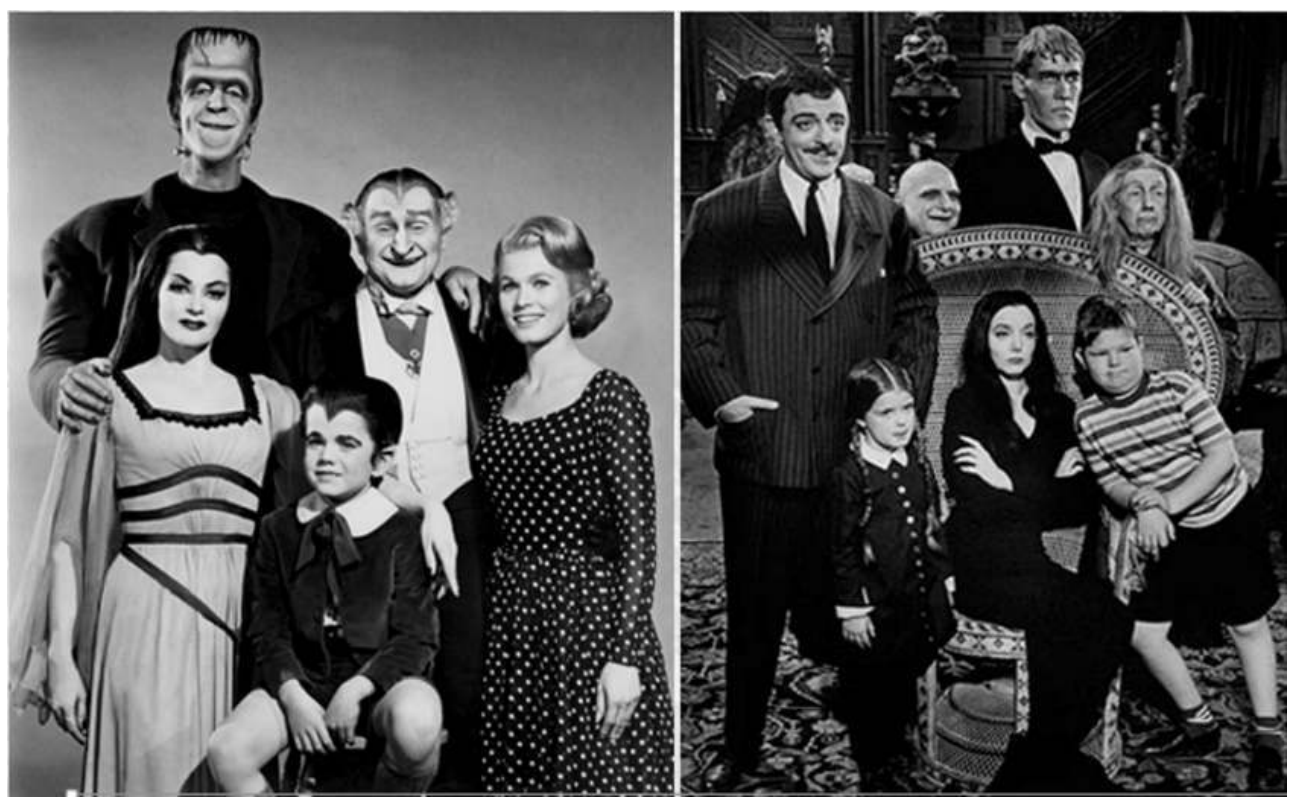

The Munsters (CBS, 1964-66, 70 ep.) \& The Addams Family (ABC, 1964-66, 65 ep.) 
9

As Helen Wheatley points out, the production histories of the two rival projects provided by each network insist that their simultaneous conception was pure "coincidence" and that neither network was stealing the other's idea (128). However, it is clear both networks were indeed trying to outdo each other and that CBS was the first out of the gate. The Munsters (CBS, 164-66, 70 ep.) had in fact been a long-sidelined project that became relevant again with the renewed popularity for these monster movies at the American cinema (See Plate 1). Universal Studios, thanks to their spate of monster films in the 1930s, owned the rights to the widely recognized visual representations of the characters of Frankenstein, Bride of Frankenstein, Dracula, Dracula's Daughter and the Werewolf, and as early as the 1940s the studio had hoped to adapt those characters to television comedy -though the initial idea was a cartoon version suggested by animator Bob Clampett in 1943. In the early 1960s, cartoon writers Allan Burns and Chris Hayward, who had achieved fame in 1959 with their popular cartoon Rocky and Bullwinkle (ABC/NBC, 1959-64), rekindled the project and submitted a treatment to CBS, but CBS producers Joe Connelly and Bob Mosher, who had made the popular WASPcom Leave It to Beaver, felt it would work better as a live-action sitcom and hired Norm Liebman and Ed Haas to write the pilot, which was entitled Love Thy Monster -a pun that was to have suburbanites immediately imagining what they would do if they had a 'monster' for a 'neighbor' (Glut 138-45; Biography: The Munsters... ). The premise was basically an attempt to turn the 'perfect family portrait' being touted on the popular WASPcoms on its ear by giving us a family of old World monsters in suburbia who frighten their neighbors but never understand why, thinking that they are in fact the normal ones. The head of the household is Hermann Munster (Fred Gwynne), a good-natured but accident-prone Frankenstein's monster who plays the 'bumbling dad' character, who faithfully kisses his wife Lily (a combination of Valerie Hobson's Bride of Frankenstein and Gloria Holden's Dracula's Daughter in the 1930s, played here by Yvonne De Carlo) as he leaves for work with his over-sized lunchbox, and who returns in the evening, booming "Honey, I'm home!", before feeding the family pet, spot -not a dog as the name implies but a giant fire-breathing Godzilla-like monster that lives under the stairs. Lily is indeed Dracula's daughter, as they share their house with her father, a vampire and mad scientist affectionately known as Grandpa (Al Lewis). To round out this mock portrait of the ideal suburban family, Hermann and Lily have two children -Little Eddie (Butch Patrick) is both a young vampire and a wolfman with a striking widow's peak and a werewolf doll that is the spitting image of Henry Hill's monster for Universal, and their teenage daughter Marilyn (Pat Priest), who is shunned as the black sheep of the family for supposedly being ugly and strange -even though she is a beautiful and charming young woman to those who are not monsters, including viewers (See Plate 2). The show's comedy is thus based on its parody of glossy family sitcoms and the comic device of absolute reversals, for in their eyes the good is bad, the ugly is beautiful and the disgusting is sublime - but at the same time, it sought to be a family-friendly sitcom, so it was not nearly as subversive as it could have been. As Helen Wheatley notes, it was in many ways a simple monster-filled transposition of Connolly and Mosher's earlier Leave It to Beaver, often borrowing storylines and dialogue from its ironic model (128). As Fred Gwynne himself similarly recalled, "It was basically The Donna Reed Show with monsters" (Jones 175), so in spite of its appeal, it seems much more could have been done to break the conventional family sitcom mold. 
In fact, ABC's 'top secret' rival project, The Addams Family (1964-66, 65 ep.) had hoped to do just that and use the monsters-in-the-suburbs premise in a more subversive way (See Plate 1). The project itself was a completely different type of adaptation, as it was based not on movie monsters of the 1930s but on the disturbing and politically incorrect onepanel comics by illustrator Charles Addams (1912-88) that had appeared regularly in The New Yorker since 1938 (See Plate 3). ABC had apparently heard about CBS's Munsters project and did not want to miss out on the children's Monstercom bandwagon. They discovered that producer David Levy had already been working with Charles Addams on a TV version of his unconventional cartoons since 1959 and the publication of Addams's macabre collection of strange cartoons and sinister Victorian memorabilia, Dear Dead Days . At first, Addams did not think television was the right medium for his work and had refused several offers, but Levy and novelist John O'Hara, both good friends of his, convinced him to green-light the TV project (Jones 175). Another motivating factor for Addams seemed to be the rumors that CBS was making a monster-family show that might just be "ripping off" his ideas (French). Indeed, much like The Munsters, Addams's onepanel cartoons had also portrayed a family whose values were the opposite of those one would expect from such a well-bred group of suburbanites (good is bad, ugly is beautiful, etc.), and who also believed that their perverse worldview was the conventional one and that everyone else was bizarre -however, in his cartoons, Addams had used these reversals for harsher and more satirical attacks on polite upper-middle-class society.

Plate 2: The Munsters and Their Universal Movie-Monster Counterparts

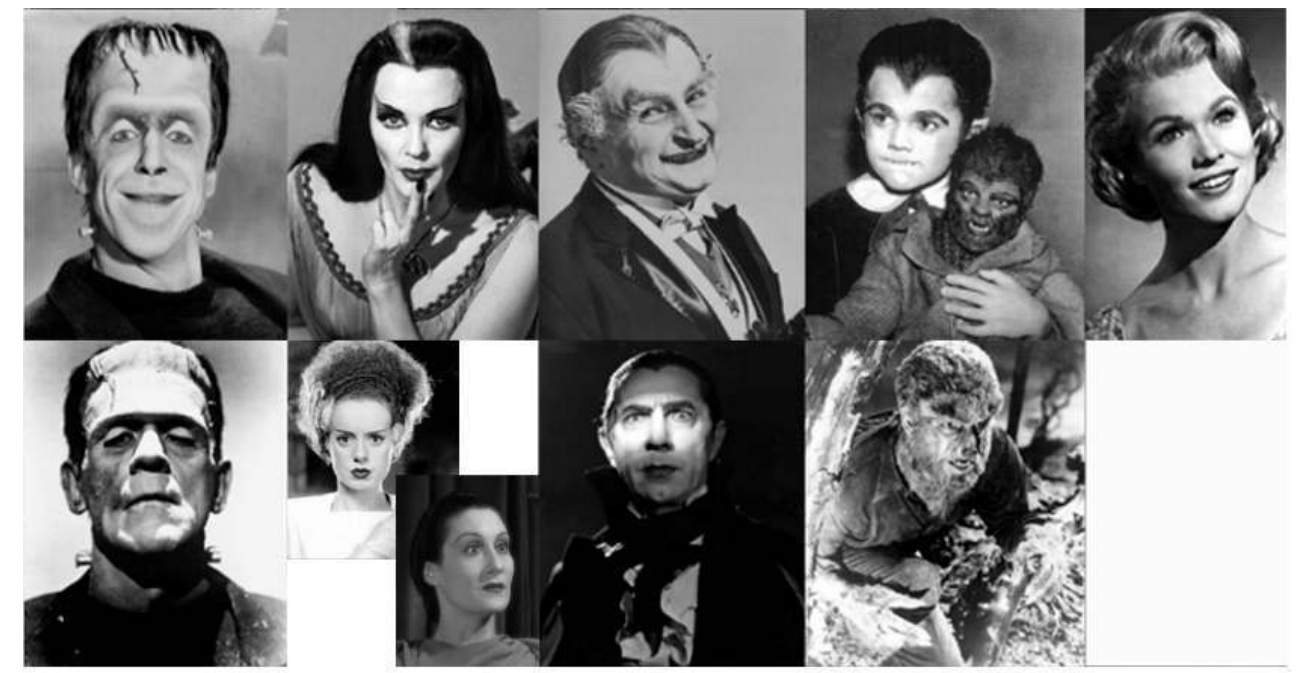

Hermann Munster (Fred Gwynne) and Boris Karloff's Frankenstein's Monster; Lily (Yvonne De Carlo) and both Elsa Lanchester's Bride of Frankenstein and Gloria Holden's Dracula's Daughter, Grandpa (Al Lewis) and Bela Lugosi's Dracula, Little Eddie (Butch Patrick) and Henry Hill's Wolfman, and finally Marilyn Munster (Pat Priest), the black sheep of the family.

11 The first step toward adapting the cartoons to television was to have the author name his trademark characters and to give them a more specific profile for the television show. One should note that, unlike the Munsters, the Addams's 'nuclear' family were not monsters per se but were eccentric and somewhat perverse human characters nevertheless endowed with certain occult powers. The head of the family was Gomez (originally 'Repelli') Addams (played by John Astin), a smilingly sadistic, cigar-smoking millionaire entrepreneur who can magically light his eternal Grouchoesque cigar, while 
his slender and cadaver-like yet charming and problem-solving wife, Morticia (Carolyn Jones), cuts the heads off of roses to display only the stems, lights candles with her fingers and emits smoke when crossing her arms (a recurring visual pun that occurs when she is asked if she 'smokes'). They live a life of macabre luxury with Morticia's Uncle Fester (in later film adaptations, Fester is instead presented as Gomez's brother). Fester (Jackie Coogan) is a bald and bug-eyed madman with a devilish grin who carries an electrical charge (he can light a lightbulb by putting it in his mouth) and who above all enjoys being tortured and playing with explosives. Morticia's mother, Grandmama (Blossom Rock), a snarly old witch who cooks up failed magic potions, also lives with them, as do their two darling children -Wednesday (likely named after the line "Wednesday's child is full of woe" from the nursery rhyme "Monday's Child"), a sadisticand severe-looking little girl who carries a headless doll named Marie Antoinette and never smiles or shows any signs of joy, and her older brother Pugsley (originally named Pubert by the author but quickly changed by $\mathrm{ABC}$ because of the overt sexual reference), a relatively kind older brother who also enjoys playing with explosives and wreaking havoc. Much like the adults, the children have unexpected superpowers, as Wednesday (Lisa Loring) can throw an adult across the room in a single judo move and Pugsley (Ken Weatherwax) is a pre-teen engineering genius and is surprisingly agile for his portly shape and size.

Plate 3: Addams Family Origins
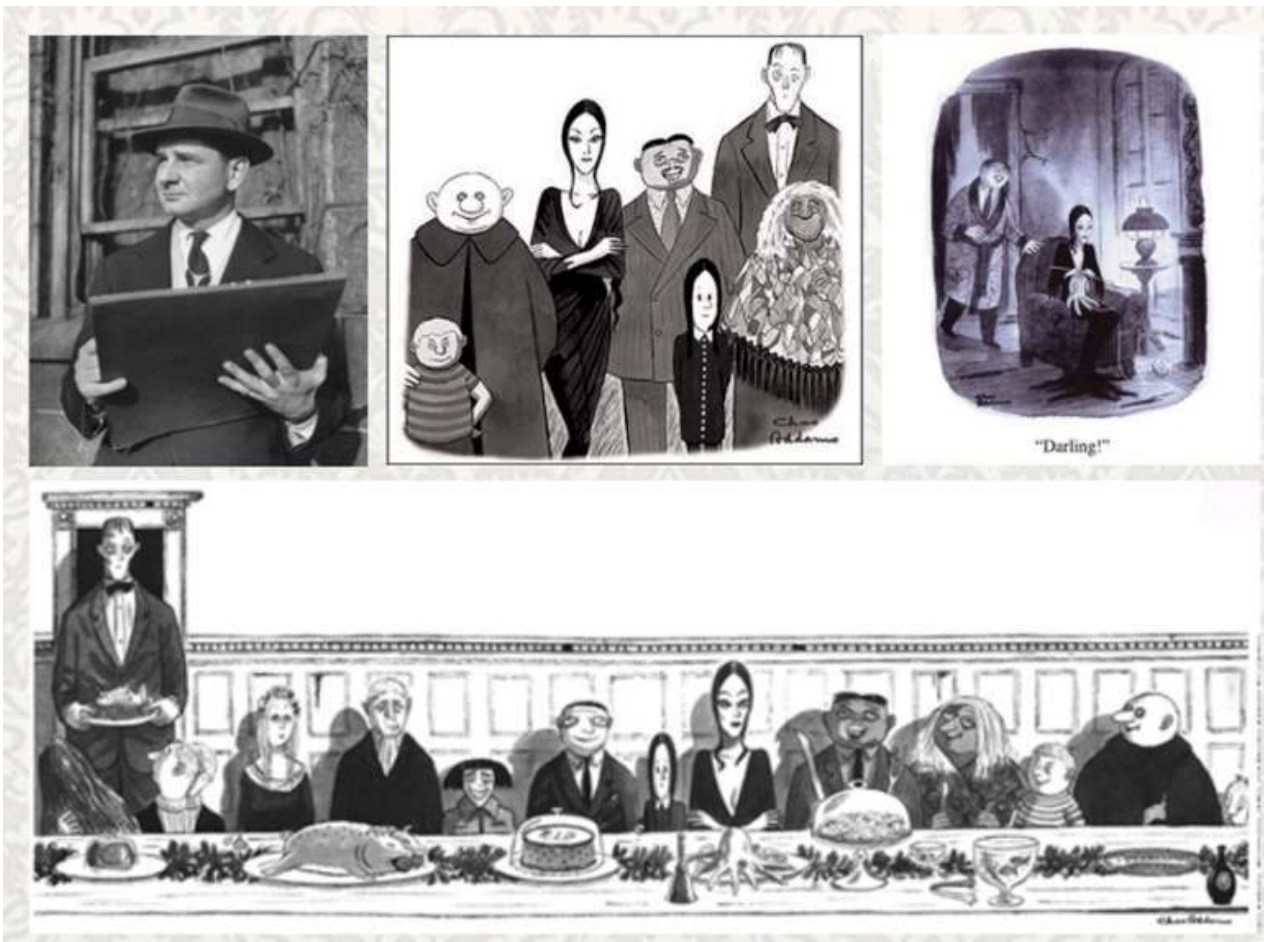

Illustrator Charles Addams (1912-1988) and a few of his one-panel 'family' cartoons

However, if the main family members were not bona fide monsters, they were nevertheless surrounded by them. In addition to occasional visiting relatives like Cousin Itt (Felix Silla / Roger Arroyo), a three-foot ball of hair that talks gibberish only an Addams can understand, the two other weekly characters, both domestics in the Addams abode, were indeed monsters. The butler and houseboy, Lurch (Ted Cassidy), was a 
cadaverous, groaning, super-strong seven-foot monster of the Frankenstein variety. In the original comic, the character's resemblance to Frankenstein's monster was even more obvious, but for the television show the connection was made less explicit, certainly out of fear of reprisals from competitor Universal for copyright infringement, though in a later television reboot, the 1998 Addams Family Reunion, Morticia praises her butler and reminds viewers that he is indeed a creature made of dead body parts: "He has the parts of many families, but he has the heart of an Addams," she proudly declares. The other domestic monster was Thing (also played by Ted Cassidy), a disembodied hand that popped out of boxes to deliver mail, hand off a telephone receiver or play chess. Thing was in fact a monster borrowed from Robert Florey's 1946 horror film, The Beast with Five Fingers, itself based on William Fryer Harvey's 1928 story of a vengeful, crawling dismembered hand that murders the inhabitants of an Italian mansion, though by making the creature a helpful and loyal hand-servant, as it were, there were no copyright issues with Warner Bros.

Both 'Monstercoms' were highly anticipated in the run-up to the 1964 fall schedule, and there seems to have been a good deal of inter-network espionage and one-upmanship going on before the shows even aired. Looking back, it seems that CBS, though having started the project first, was making far more changes in view of ABC's rival project. For example, after completion of the unaired pilot for CBS, three key changes were made when Love Thy Monster first aired as The Munsters. First of all, the show would switch from color film to black and white, both because CBS had learned that The Addams Family would be in black and white and because it was decided that color film made the monstercharacters far too garish and disturbing (Obias), whereas they were shooting for amusing and endearing. There was surely the added notion that black and white would better draw the connection to the 1930s film monsters on which the characters were based. In addition, two characters on The Munsters were quickly altered. When CBS producers learned that Pugsley Addams was to be made more endearing than the little terror that they had expected, Eddie Munster was similarly made to be more harmlessly cute and even sweet. Producers were also worried that the actress originally hired to play the Lily character (Joan Marshall, billed as 'Phoebe Munster') was far too similar in appearance to Morticia Addams for the network not to be accused of 'copying' their rival, so Yvonne De Carlo, already on contract with Paramount, was asked to step in after the filming of the second pilot (De Carlo 7).

As the projects were developed simultaneously and first aired only a week apart, one cannot say that one was the original and the other a mere copy, although they were both clearly lookalikes, and both were based on a very similar premise -that of providing satirical versions of what the dull WASPcoms were presenting elsewhere as the ideal American family. As Wheatley points out, in addition to both relying primarily on the normal/abnormal inversion device, the two programs often came up with nearly identical storylines with which to showcase it (22-23): for example, on an episode of The Addams Family (1.22), Gomez loses his memory and becomes what viewers would see as a normal, caring suburban father, much to his family's horror; the following season, on a Munsters episode entitled "Just Another Pretty Face" (2.17), an experiment gone awry similarly "horribly disfigures" Hermann, leaving him a normal-looking (to others) human being (i.e., actor Fred Gwynne without monster make-up).

That said, there were stark differences between the households at 1313 Mockingbird Lane (The Munsters) and at 0001 Cemetery Lane (The Addams Family). Most obviously, the two 
families were of starkly different social classes, for the Munsters were seen as a lowermiddle class if not a working-class immigrant family (Grandpa had moved to the U.S. from Transylvania) trying to live the American dream in suburbia, while the Addamses were aloof, eccentric and independently wealthy members of the upper middle-class, who saw themselves as pillars of the community but were oblivious to the harm and even pain they might cause others. This was of course the spirit of the original cartoons by Charles Addams in The New Yorker: rather open mockery of the wealthy and highly educated who flattered themselves with a feeling of flawless propriety and ideal values ${ }^{3}$. Not surprisingly, the $\mathrm{ABC}$ show seemed more intelligently satirical than its $\mathrm{CBS}$ counterpart, which in keeping with the older network's overall style was more conventional and conservative, even when it came to fantasy sitcoms. $A B C$ clearly took far more risks in going against the typical sitcom grain, and seemed to take nearly every shared comic device one step further, if not too far. For example, if the Munsters had Godzilla-like 'Spot' living under the stairs as a mock house pet, the Addamses had not only Kitty the housecat (actually a lion), but also a pet vulture (Zelda), a pet octopus (Aristotle), a pet jaguar (Fang), pet piranhas (Tristan and Isolde), and a pet tarantula (Homer) -not to mention Cleopatra, Morticia's favorite houseplant -an African Strangler who actually strangled visitors. Not surprisingly, while the Munsters regularly sent visitors running away in fright, the Addamses inflicted far more real harm on unsuspecting guests and neighbors and were far more oblivious to it -and the most disturbing in this regard may have been the cigar-toting Gomez character, who laughed off any pain he inflicted as if he were a sadistic Groucho Marx. In addition, the family's penchant for violence extended to themselves as well, as one of the key inversions played up on the ABC show was that pain was in fact pleasure. Hence the Addamses were as gleefully masochist as they were sadistic -with Uncle Fester enjoying a good stretch on a medieval rack or relaxing in an iron maiden, Pugsley playfully being tortured by his sister, and their parents sleeping on 'his' and 'hers' beds of nails, swallowing swords and then dueling with them -for if "their house was a museum", as the opening theme song told us, it was clearly a museum of medieval torture devices. Add to this outward and self-inflicted violence a dark love of the occult, particularly among the women (e.g., Grandmama's dark spells, Morticia's growing nightshade and headless roses in her garden -i.e., a cemetery -and Wednesday's chopping the heads off of her dolls with a guillotine and burying them in her own doll cemetery in the backyard) and you have the makings of quite a shockingly Gothic inversion of the ideal family.

Perhaps most shocking -especially given the bland TV landscape of the period -were the constant references to the main couple's lust and active sex life. For if Hermann and Lily Munster slept in a double bed -something quite rare on early sitcoms ${ }^{4}$-sex was never even alluded to on the CBS show. Morticia and Gomez, on the other hand, were never afraid of public displays of affection, or even of frenzied lust -most often triggered when Morticia happened to utter any word in French or called Gomez "Bubbeleh", a Yiddish term of endearment. To make matters worse, their idea of foreplay often involved playfully using horsewhips or swords on each other, hinting at the idea that their sadomasochism discussed above clearly ran over into their love life. If on the surface this was mere mockery of middle-class propriety and stifled emotions, it was indeed the only place on American television at the time that viewers could see such overt sexual references -as they seemed to be safely framed and cut off from reality by the fact that it was a 'fantasy sitcom' family. For critic Robert Garcia, Gomez and Morticia's overt sexuality was the biggest breakthrough on American television at the time (45), and other 
critics have stressed the importance of Morticia's and even Lily's more open sexual freedom and decisional power within the mock suburban households as a tempered feminist breakthrough on network TV, though their need to do housework and prepare meals, key features of the family sitcom models they were lampooning, somewhat hindered those more feminist efforts ${ }^{5}$.

Even if The Addams Family was clearly the far more unconventional of the two programs, one must recognize that both sitcoms had a very strong countercultural appeal. Although billed as harmless escapism, metaphorically these programs could be seen as an all-out attack on the decidedly conventional and wholesome family values that were being promoted as the American ideal elsewhere on all three networks. This open mockery may have captured some of the growing spirit of rebellion among children and young people of the 1960s, who would soon come to more violently protest against that same conservative rhetoric throughout the decade and who would stage a countercultural revolution of their own that the television landscape would otherwise fail to include. For example, in addition to the proto-feminist message mentioned above, one of the strongest tropes in both 'Monstercoms' was using the normal/different and us/them inversions to tout a thinly veiled message on tolerance and acceptance of 'otherness'. As both Helen Wheatley and David Marc have pointed out, both sitcoms, from their earliest episodes, stressed this call for acceptance of diversity, thereby "producing comedy out of suburban intolerance" (Wheatley 19, Marc 109). For example, in the fifth episode of The Addams Family, Gomez and Fester fret when the children are invited to a birthday party down the street, for the neighbors are so "different" and, horror of horrors, have a white picket fence, geraniums and daisies. Morticia takes the high road and insists, "Now, now... We must be tolerant of our neighbors." Similarly, though even more strikingly, the second episode of The Munsters used a similar device to rather blatantly attack racism in white surburbia. In an exchange with the mailman on his rounds, the Munsters' nextdoor neighbor complains, "This was a nice neighborhood until they moved in," to which the mailman asserts, "Keep them in their place. That's the ticket." Although done metaphorically here, such references to racism towards minorities or immigrants moving into the suburbs could not be found in the gleefully whitewashed WASPcoms and Ruralcoms of the period.

Thus these Monstercoms had much in common with the broader group of fantasy sitcoms and Magicoms they were briefly a part of, as they were all based on the same basic premise -that of the outsider or misfit trying to be accepted in America's small towns and suburbs -although in these cases the outsiders in question included witches, genies, talking horses and automobiles, aliens, ghosts, vampires and other monsters who emigrated from Transylvania, and sadistic outcasts who dabbled in the occult. If there was no real diversity on American television in the early sixties, it was cleverly packaged for young people on the fantasy sitcom, and this distancing device would soon be transferred to science-fiction dramas of the late 1960s that still targeted younger audiences -most notably through programs like Star Trek (NBC, 1966-69), which projected a future in which all interplanetary species (like our races) would be treated as equals, and in which interracial relationships would be accepted without question leading to the very first interracial kiss on scripted American television, between Cpt. Kirk (William Shatner) and Lt. Uhura (Nichelle Nichols) in the show's third season (3.10) ${ }^{6}$. In both cases -that of the fantasy sitcom and the later sci-fi adventure -themes of 
diversity and acceptance could be broached in a way that could not even be attempted on more grounded and realistic series.

However, in the end, these two Monstercoms, in spite of the high hopes and internetwork espionage, did not draw the massive audiences the networks had hoped for. Of the two programs, The Munsters did slightly better, peaking at $\mathrm{n}^{\circ} 18$ during the first season to The Addams Family's $23^{\text {rd }}$-place showing, and neither series made it into the top thirty for their second season, causing both networks to simultaneously cancel the programs in 1966. However, both programs were, in the end, clearly ahead of their time, for they would snowball in popularity among young audiences for generations through syndication, and lead to a series of big-budget feature films in the early 1990s in the case of The Addams Family and, in the case of The Munsters, to several television series reboots, both animated and live-action, as well as a big-budget made-for-TV movie entitled Mockingbird Lane in 2012. When they first aired, however, these Monstercoms did not meet the networks high expectations, and the sitcom landscape suddenly lost its 'creature double-feature', although in 1966, immediately after their cancellation, those monsters would quite crop up within another unsuspecting television genre.

\section{Dark Shadows on the Daytime TV Landscape}

By 1966 and the simultaneous cancelation of both The Addams Family and The Munsters, $A B C$ had clearly failed in its effort to outdo CBS, and it seemed that both networks had given up on the idea of shaking things up by introducing Gothic ghouls and creatures into the otherwise tranquil TV sitcom landscape. However, that same year, Gothic monsters taken straight from Victorian literature would make a disruptive entrance into a different but just as calmly conventional TV landscape, that of the daytime soap opera. Much like the monsters' foray into primetime sitcoms, it would again be the result of $A B C$ creating a completely unexpected hybrid -that of the daytime Gothic-horror soap opera in another somewhat desperate attempt to somehow topple leader CBS, and it was again an experimental idea that $\mathrm{ABC}$ hoped would appeal to their main target audience, young people, by giving an unexpected twist to what most viewers under twenty saw as a bland product (Fox 40-41). This time however, $\mathrm{ABC}$ would go it alone.

21 Just before this new experiment, the daytime landscape was similar in many ways to the nighttime landscape that the Monstercom had tried to shake up -as it was also completely dominated in terms of ratings by CBS, who had successfully adapted the radio 'soap opera' format to TV ahead of the other networks and multiplied their success with lookalike programs that collectively created the new standard. One must remember that until the early 1950s, there was no daytime TV and networks broadcast about two hours of programming every evening -primetime was in fact the only time. Radio, however, had provided afternoon programs aimed at housewives as early as 1930 (the first such radio serial being Painted Dreams on NBC Blue, before it became ABC). In the early 1950s, networks started to provide afternoon programming similarly aimed at housewives and at children on their return from school, programming that consisted mainly of game shows, syndicated sitcom reruns and, thanks to CBS, the first TV soap operas.

From the dawn of daytime TV, CBS immediately brought the soap opera format to television, with two fifteen-minute 'sister shows' that aired back-to-back and immediately took the top two spots in afternoon ratings from 1951-1956: The Search for Tomorrow (CBS 1951-82; NBC 1982-86) and The Guiding Light (1952-2000), the latter of which 
had been a long-running radio soap on NBC since 1937 but was taken over by CBS in 1947, as if in anticipation of its pending transfer to television. CBS and show sponsors Proctor and Gamble found in the daytime soap a lucrative partnership, for the teleplays were cheap to make and yielded both top ratings for CBS and greatly expanded sales for the sponsored products, and thus in 1954 CBS would add a third serial, The Secret Storm (1954-74), a perennial top-5 hit sponsored by America Home Products. Two years later, CBS and Proctor \& Gamble would add two more soaps to their afternoon line-up that would allow the network to round up all top-five spots every year until 1965: The Edge of Night (CBS 1956-75; ABC 1975-84) and As the World Turns (1956-2010), which would dethrone The Search for Tomorrow in 1958 and hold onto the number-one spot throughout the 1960s. Thus CBS would rule the afternoon roost virtually unopposed for well over a decade, with rival networks finally adding their own soap operas in 1963 and 1964: ABC's General Hospital (1963-present) and NBC's The Doctors (1963-82), Another World (1964-99) and Days of Our Lives (1965-present) -though these shows would remain at the very bottom of the top ten in ratings for many years, far behind CBS's unbreakable monopoly of the top five spots. By the early sixties all of these serials had expanded from 15 minutes to a half-hour, were all broadcast live from New York City and had become the industry standard for afternoon television ${ }^{7}$.

If the process and melodramatic style were the same for all of these daytime serials, producers went to great lengths to try to find new and unusual premises in order to stand out from the competition. If the first soap, Guiding Light, initially focused on the plight of a woman whose husband was an alcoholic, the two programs that followed both dealt with the main characters' mourning and search for new love-Search for Tomorrow was about a Midwestern widow who had to open an inn to keep her children from her vicious in-laws, and The Secret Storm, its corollary, was about a widower raising three children and dealing with his feuding love interests. Then came the 'profession-based' soaps, including one dealing with the private life of a small-town police detective (Edge of Night), another about a lawyer and his bored housewife (As the World Turns), and then three from CBS's rivals, all of which dealt with the professional and private lives of doctors and nurses (General Hospital, The Doctors and Days of Our Lives -though the latter focused far more on Dr. Horton's family-life than the goings-on at the hospital). Yet another offering from NBC, Another World, would try to stand out by focusing on conflicts between two families of different social classes, hence the title.

This was thus the landscape of afternoon television in 1965 when $A B C$, already getting ready to pull the plug on The Addams Family, called in young producer Dan Curtis to brainstorm ideas for new afternoon programs. At the time, Curtis was not yet the master of short-order horror that would eventually be his claim to fame, but he had already made a name for himself in the production of sports programs, even winning the 1965 Emmy for Achievement in Sports for his long-running CBS Golf Classic (1963-73). Having told $A B C$ executives Brandon Stoddard and Leonard Goldstein he was interested in moving on to drama, he came to them with a quite unusual pitch. He claimed that he had had a dream that summer, a vision of a young woman traveling by sea and by rail to "a house of dark shadows" in search of her destiny, a place where she would get caught up in the machinations of an eccentric, wealthy family that had dark secrets. Goldstein jokingly responded that Curtis had unwittingly pitched Jane Eyre, to which Curtis deadpanned, "Is anyone doing that on daytime right now?" (Thompson 18-21). ABC hoped that the bold premise would draw in young people -particularly girls -after school in the 
4:00 pm timeslot and decided to give the 'mysterious Gothic' premise a shot. It was a decision that would give rise yet another unexpected hybrid program and a future cult favorite from ABC, Dark Shadows (1966-71, 1,225 ep.), an experiment that would forever change the trajectory of Dan Curtis's career in film and television.

The first ten months of the series stuck close to Curtis's initial idea of making a modern Jane Eyre. The main actress was young Alexandra Moltke, who played Victoria Winters for 627 episodes, or half of the run of the series. Winters was a young governess who came to work at a mansion in Collinsport, Maine, in the hopes of solving the mystery of her own identity, and the first episode began with the her now-famous voice-over: "My name is Victoria Winters...my journey is just beginning...”. Brontë's Jane Eyre was thus the main subtext for the early seasons, and was reinforced both through Victoria's relationship with the wealthy and brooding Burke Devlin (Mitchell Ryan), and a much later subplot in the series involving the discovery of a mysterious "madwoman in the attic" (ep. 707-748). However, nine months into the first season, ratings that were never very good to begin with were growing even worse, and Curtis claims that it was his daughters who insisted he take the show a step further in bring in bona fide Gothic monsters (Thompson 23). The first attempt was to bring in a ghost, the spirit of Laura Stockbridge who haunts the halls of Collinwood mansion in search of her surviving son David. With an immediate boost in ratings, Curtis had decided that as the ghostly subplot faded he would bring in something even more frightening (Thompson 24). This is how the character of Barnabas Collins (Jonathan Frid, ep. 211-1245), a vampire awakened by a grave-robber on the Collins estate, came to be -and the character, roughly based both on Polidori's "The Vampire" and Bram Stoker's Dracula, would immediately upstage Victoria as the program's main character and become a pop icon among audiences for generations. Barnabas was an angst-ridden vampire searching for both revenge and for redemption -long before David Boreanaz portrayed a similar vampire on Buffy the Vampire Slayer and Angel in the late 90s and early 2000s, and even longer before Robert Pattison gave us another teen version as Edward Cullen in the Twilight film series (Note that the name Cullen may very well have been inspired by Dark Shadows' Collins). One might think that a daytime soap opera could not give us the gore and special effects needed to properly present a blood-thirsty vampire, that it would be necessarily bland and camp, and it is true that Curtis often complained about not being able to show more blood or more vivid horror (Thompson 24 ), but this is a case in which the low production values and highly-censored medium may have worked to the show's advantage, for without the gore, the vampire myth became more of a metaphor for loneliness, isolation and angst, making for a far more intriguing and anything-but-soulless character. $A B C$ was immediately flooded with fan letters for Frid and his Barnabas character, convincing Curtis not to kill the character off as quickly as he had intended (Jowett \& Abbot 49). Within two months, ratings had doubled and at its peak Frid would be receiving over 5,000 fan letters a week (Fox 40). It was quite apparent that the lonely, angst-ridden Barnabas character had struck a much stronger chord with children and teens than the Monstercoms had managed to do a few years earlier, and the fan letters that came in clearly demonstrated that. These included encouraging letters from young children addressed to 'Uncle Barnabas', commiserating with the reluctant vampire on how hard it is not to be "bad" at times, and many others from teens who clearly identified with the character as a misunderstood outcast (Clark et al. 124). As Jowett and Abbot point out, Harry Benshoff's audience research has even suggested that young gay and lesbian viewers were especially drawn to the program, strongly identifying with Frid's character (206-207; Benshoff "Resurrection..." 50-61). 
Further proving the show's new appeal to young people, as well as ABC's desire to capitalize on it, was the massive merchandising campaign that soon followed, which included coloring books, comic books, bubble-gum and children's Halloween costumes (Jowett \& Abbott 208).

As the series progressed, two other supernatural main characters would be added to further spice things up, as it were. Barnabas would thus soon come face to face with Angelique Bouchard (Lara Parker, ep. 368-1245), the witch whose curse had turned him into a vampire and his eternal nemesis on the show in spite of their obvious sexual attraction to each other. Later in the series, a younger male lead would be added in the character of Quentin Collins (David Selby, ep. 646-1230), a Byronic and world-weary young man inflicted with the werewolf's curse (See Plate 4), and the addition of this young heartthrob would give ratings yet another boost, with twenty million weekly viewers in late 1969 (Clark et al. 46). Quentin's character also dabbled in witchcraft, which would be a vehicle for another breakthrough in afternoon storytelling-as Quentin created a "Stairway through Time," a magical portal that characters would soon use to time-travel to 1795 , to 1841 , to 1897 and back to the present, or more precisely to a different present due to changes made in the past. It was in this manner that the soap opera in late seasons took viewers to 'parallel universes' both in the past and the present, allowing actors to multiply and vary their own roles in a most original, if at times somewhat confusing, manner.

\section{Plate 4: The Main Cast of Dark Shadows}

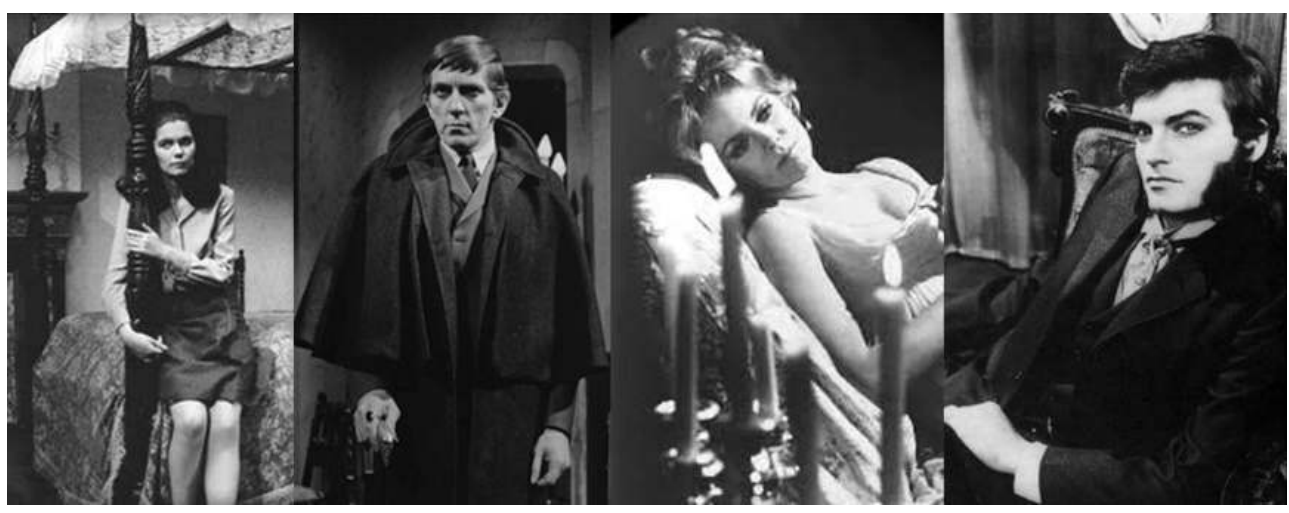

The Jane Eyre character, Victoria Winters (Alexandra Moltke), the vampire Barnabas Collins (Jonathan Frid), the immortal witch Angelique Bouchard (Lara Parker) and the werewolf Quentin Collins (David Selby)

If the main cast members were then a vampire, a witch, a werewolf and a modern Jane Eyre, it should be noted that there were dozens of other overlapping literary subtexts added to the series, each lasting from a few to even hundreds of episodes, and most of which were taken straight from landmark works of traditional Gothic or Victorian literature. To start with, the 1960s story-line (before time travel became involved) included a pastiche of rather easily recognized literature-based subplots. For example, Burke Devlin's wrongful imprisonment and revenge on the Collins family (ep. 1-201) is a reworking of Dumas's The Count of Monte Cristo, while the creation of a man named Adam in a laboratory and the creature's insistence on his creator making him a mate (ep. 466-636) bring back Mary Shelley's Frankenstein. Similarly, Elizabeth Collins's irrational fear of being buried alive (ep. 512-672) seems borrowed from Poe's "Premature Burial", while repeated storylines about the ghosts of a dead maid, relative (ep. 639-700), seafarer 
and governess (ep. 1071-1109) all haunting the two children at Collinwood, David Collins and his younger cousin Amy Jennings, are repeated reworkings of Henry James's "The Turn of the Screw". These 'present day' storylines even include a touch of H. P. Lovecraft, for Barnabas temporarily falls under the control of Leviathans, the hideous race of beings that ruled the earth before mankind but still secretly walk among us (ep. 866-950), a nod to Lovecraft's shared universe in his Cthulhu Mythos and in stories such as "The Dunwich Horror"s.

In addition, once time travel was added to the quickly crisscrossing timelines, the number of loose literary subtexts multiplied as well. For example, in the 1795 time shift, timetraveling Victoria is falsely accused of witchcraft and put on trial (ep. 400-461; cf. Arthur Miller's The Crucible), and Barnabas walls up his enemy Reverend Trask in a wine cellar, while the latter's ghost will later attempt to return the favor (ep. 762-884; cf. Poe's "The Cask of Amontillado"). In the 1897 time shift, even more Poe references abound, as timetraveling Quentin is haunted by the heartbeat of a man he has killed (ep. 700-748; cf. "The Tell-Tale Heart") and is later trapped in a torture chamber reminiscent of "The Pit and the Pendulum" (ep. 778-814). Add to this a portrait of Quentin that can take over his werewolf curse for him (ep. 749-834; cf. Wilde's The Picture of Dorian Gray) and the mayhem that ensues from attacks by the murderous, disembodied hand of Count Petofi (ep. 778-814; cf. William Fryer Harvey's "The Beast with Five Fingers," already mentioned in our discussion of The Addams Family above), and Quentin's turn-of-the-century escapades seem a compendium of early horror references.

Finally, the last season's rather confusing parallel universes created by careless time travel also have their share of literary subtexts, for Angelique's death, in a parallel modern world, after her true nature is revealed (ep. 969-1060) is reminiscent of Daphne de Maurier's Rebecca, while Cyrus Longworth's laboratory experiment that creates his evil alter-ego John Yaeger (ep. 978-1035) is a simplified Jekyll and Hyde from Stevenson; similarly, the newly created 1841 parallel universe includes a reworking of Shirley Jackson's “The Lottery", when Catherine wins the dreaded 'Cursed Tower Room Lottery' (ep. 1194-1245), and Emily Brontë's Wuthering Heights is superimposed on Bramwell Collins and Catherine Herridge's doomed love affair in the last episodes (ep. 1186-1245).

Though these numerous, overlapping literary subtexts were 'light shadows' at best of the classic works that provided the source material, at the very least it was a coordinated effort on the part of the show's writers (Art Wallace, Ron Sproat, Sam Hall, Malcolm Marmorsteinn and Gordon Russel) to actually bring in literary subtexts, something that was quite rare at the time-and unheard of on afternoon television. And unlike the Monstercoms discussed earlier in this study, writers borrowed directly from the literary source texts rather than from movie-monster versions or loose cartoon adaptations of creatures from Gothic literature. That said, purists would certainly find fault in the loose adaptation techniques and the necessarily cheap production values in which they were packaged, for Dark Shadows was a very low-budget affair indeed.

By today's standards, perusal of even a few episodes of Curtis's series would provide a laundry list of goofs and short-comings, nearly all of which were due to the program's low budget and impossibly tight shooting schedule [even at its peak, the budget was only $\$ 70,000$ for five weekly episodes (Thompson 55)]. Generally speaking, the program even seemed more rushed and unrehearsed than more standard soap opera fare at the time, for as there was no time for second takes with its live-to-tape format, many flawed scenes remained when an episode aired. For example, a character may stumble as he walks into 
the frame, or the supposedly heavy front door of the mansion may, when slammed shut, flimsily (and hilariously) pop back open. Properly framing the shot seemed to be a particular problem, as there were frequent intrusions of the heads of crew members at the bottom of the frame, or crew members still scrambling out of the frame during the fade in, and, most often, the visibility of the second camera reflected in a mirror or the boom mic slipping into the top of the frame. As a result, those who later mocked the show began to float the unkind nickname 'Mic Shadows', though fans of the program tend look back at these beloved gaffs as a key part of the show's charm (See Plate 5).

Curtis himself recalls how it was "nickel-and-dime television at its best" (Thompson 55), a statement that points to both the problems of budget constraints and the sometimes ingenious methods the crew had to devise to overcome them. For example, when there was no budget to hire new actors, some regular cast members were asked to 'disguise' themselves to play an extra role (and this in addition to the alter-egos of their own characters that they might be playing in parallel time). This practice was most rampant during the 1967 AFTRA (American Federation of Television and Radio Artists) strike, when few actors would cross the picket-line to resume taping the show (Kellow 427-28). However, what the shooting crew pulled off in spite of the budget restrictions was perhaps the most astonishing. Lighting director Mel Handelsman's skillful work, particularly in the first season of black-and-white shooting, cleverly brought the shadow work and contrasts of Universal's popular horror films and film noir to afternoon TV (Thompson 56). Similarly, cameraman Stuart Goodman had to come up with ingenious low-budget tricks to provide special effects, which included covering the camera lens with plastic wrap and dabbing it with vaseline on the edges to create a dreamlike filter, or setting a small fire in a bucket and hanging that bucket right in front of the camera lens to give the impression the characters were trapped in a blaze (Rossen). Scenic design also made the best of the low budget and the small set space it had to work with [four tiny sets the total size of which was no bigger than two lanes of a bowling alley (Thompson 56)]. Set designer Sy Thompson would thus make a name for himself on the program, creating the most elaborate sets on daytime TV in spite of the limitations -and going on to win four Emmys for his work on later soap operas, such as The Bold and the Beautiful in the 1990s. Finally, the crew member who would go on to the greatest fame was in fact makeup artist Dick Smith, a pioneer in latex and plastic facial prosthetics, who would for example apply his soon-to-be trademark aging techniques to the Barnabas character, particularly for the later film adaptation in 1971, and would gain fame for his work on films like Little Big Man, The Exorcist, and Taxi Driver, later winning an Oscar for his work on Amadeus and a Lifetime Achievement Oscar for make-up effects in 2012 (Smith). Curtis's low-budget horror soap was thus a trial by fire for many great names in the film industry. 


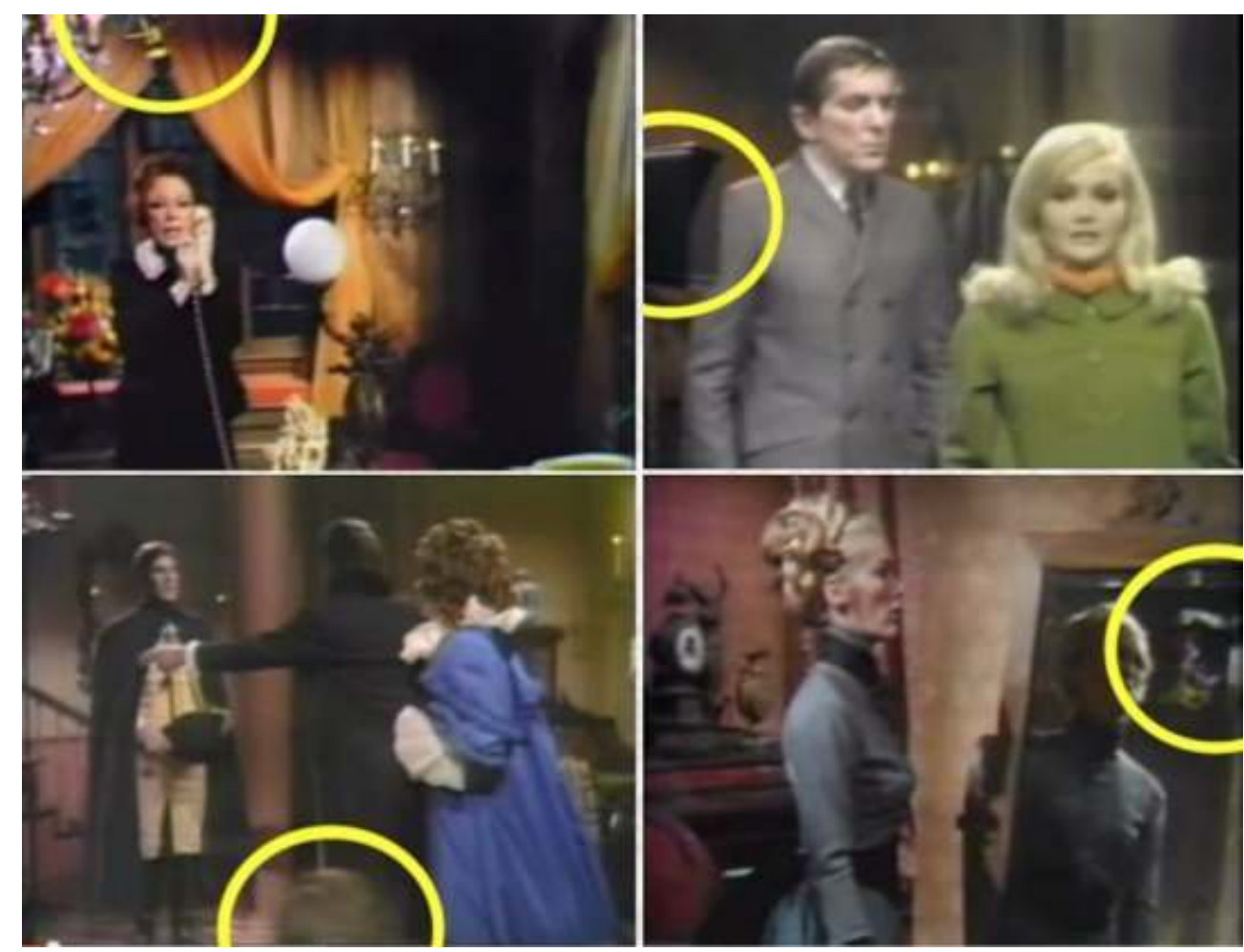

A few samples of shots from the series in which the boom mic, second camera or crew member's head is in the shot (circled).

In the end, this experimental program was a success for $\mathrm{ABC}$, developing a faithful following and solid fan-base, averaging about ten million weekly viewers, with a peak third season at an average of 16 million weekly viewers (and a $28.8 \%$ share of its time slot) (Leigh-Scott 104). More importantly, this was the first time ABC could boast that they had beaten both CBS and NBC in their afternoon timeslot, for Dark Shadows garnered far more viewers than the other networks' rival 4:00 pm game shows and talk shows. Still, though the show did bring in teenagers, it did not draw the massive audiences that more traditional afternoon soaps attracted, and Curtis's series never got any higher $n^{\circ} 11$ in the afternoon Nielsen ratings during its run, and even dropped to $n^{\circ} 16$ in the final 'parallel universes' season. By April of 1971, and in spite of a slight rebound in ratings during the very last episodes of season 6, $\mathrm{ABC}$ decided to cancel Dark Shadows. Thousands of fans wrote to the network to complain, and membership in Dark Shadows fan clubs actually skyrocketed (Benshoff Dark 91-92), instantly making it a cult favorite. However, a slight drop in ratings for its last season may not have been the main factor in the program's cancellation. ABC may have wanted to shake up their own schedule, in response to CBS's surprising 'great rural purge' of 1971, during which CBS abruptly cancelled all of its rural and fantasy sitcoms, even those at the very top of the ratings chart, in order to experiment with more hard-hitting, topical and controversial sitcoms like All in the Family (1971-79). However, the biggest factor may simply have been that Curtis did not fight to keep it on the air, and even welcomed the cancellation. In an interview featured on volume 16 of the 2005 Dark Shadows DVD box set, Curtis recalls the relief that came with news of the cancellation, for he was completely out of ideas for plot twists and subtexts that could keep the series going and needed to step off of the relentless treadmill such a 
show had come to represent: “I couldn't squeeze my brain any harder to come up with just one more story," he recalls.

However, in spite of the death knoll of the series and its eulogy-like last lines of voiceover: “...for as long as they lived, the Dark Shadows of Collinwood were but a memory of the distant past," the series Dark Shadows would have an afterlife, long before Curtis would try to reboot the series on NBC in 1991. Much like the Monstercoms discussed above, Dark Shadows would garner new audiences and repeat audiences when it was sold into syndication-making it the first soap opera ever to be released as reruns (Jowett and Abbott 204). Soap operas, with their drawn-out seriality and the lack of appeal of watching episodes out of order, were never put into syndication after cancellation, and that fact that Dark Shadows was says a great deal about its hybrid appeal. In addition, at the time of cancellation Curtis had already started moving the Dark Shadows universe from the small screen to the big screen. In fact, during the entire run of the series, Curtis had been honing his feature-film-making skills with a series of made-for-TV Gothic horror movies, many of which were critically acclaimed, including Doctor Jekyll and Mr. Hyde (1968) with Jack Palance, the first in a series of more serious teleplays that would stretch into the 1970s with The Picture of Dorian Gray (1973), Dracula (1973) and The Turn of the Screw (1974). However, in 1970, Curtis made his first leap to the big screen by adapting Dark Shadows, thus taking yet another unprecedented step -that of adapting a soap opera into a feature film. Even more enticing to Curtis, perhaps, was the fact that he could take advantage of the death of the Hays Code in 1968 and the rise of exploitation films to finally bring vivid blood and gore to Collinwood. For the first feature, Jonathan Frid agreed to portray his iconic Barnabas as a murderous, blood-thirsty vampire -even though he would concurrently play the pensive and angst-ridden version of the same character for the last TV season (that said, Curtis had the TV character 'trapped in a coffin' for several weeks in 1971, sequestered by a writer-character who wanted to expose his true nature to the world -thereby freeing up Frid to do the film). Entitled House of Dark Shadows, the MGM film reboots the story of Barnabas's arrival at Collinwood, making him a vicious killing machine hell-bent of breaking the curse of his vampirism so that he could marry a young governess, who is the spitting image of his long-lost love, Josette. In spite of the gore and deviations from the cult series (or perhaps thanks to them), the film did extremely well at the box office, though many feel that the film's in-your-face gore and horror devices may have inadvertently led to the drop in TV ratings, as many parents who saw the film may have thereafter forbade their children from watching the TV show, assuming they were of the same style and tone (Hamrick 163). In any case, before the first feature was released, Curtis and MGM had already begun filming on its sequel, Night of Dark Shadows, but as Frid declined to once again don Barnabas's cape and fangs, the second film was instead a reboot of the story of another leading character, Quentin Collins (David Selby), who arrives at Collinwood and finds himself possessed by the ghost of a dead ancestor and attacked by the ghost of his ancestor's mistress, the witch Angelique (Lara Parker). With less gore than the first feature, the absence of Barnabas Collins and a rather disjointed story-line, the film did not do nearly as well, and when MGM requested a third Dark Shadows feature, Curtis refused, as he was already working on yet another completely unexpected hybrid format, one that would combine fantastic tales and the supernatural with yet another more conventional television subgenre... 


\section{Curtis Stalks the Nighttime Police Drama with another Hybrid}

format and towards feature and made-for-TV movies that would, rather paradoxically, give rise to a new type of hybrid series for $\mathrm{ABC}$, who was still futilely trying to snatch the top spots in primetime ratings from the unshakeable network leader CBS and perennial second-place NBC. Much as they had done with the primetime sitcom in the mid-sixties, or with the daytime soap opera in the late sixties, $A B C$ hoped this time to have higher ratings and increase its appeal among younger demographics by adding monsters from Gothic literature and other supernatural creatures to the traditional crime drama, a subgenre that was already being renewed in the early 1970s and was finally getting a fair share of top-20 slots in ratings.

In the 1950's, crime dramas adapted from popular radio shows of the 1940s were a staple of primetime programming, even if they were far outnumbered by comedy-variety shows and sitcoms that were similarly adapted from radio shows. At the time, NBC's Dragnet (1951-59) made the top 20 for six consecutive years from 1951-57, peaking at number 2 in 1953-54, while CBS, who cornered the market in TV comedy, also found success with the police drama The Line-Up (1954-60) for a few years, just before crime drama was edged out by the sudden dominance of the Western from 1957 to the early sixties, as well as the still-growing popularity of the sitcom. $\mathrm{ABC}$, with no radio drama to adapt in these early days, was left out in the cold with little to offer. In terms of the few crime dramas that made it into the top 20 in the early sixties, CBS was still in command with its highranking Perry Mason (1957-66), but ABC made one of its early forays into the top ten between 1959 and 1961 with 77 Sunset Strip (1958-64, peaking at $n^{\circ} 7$ ) and with The Untouchables (1959-63, peaking at $n^{\circ}$ 8). In 1964, ABC again made a slight dent in CBS's armor with more experimental dramas like the fantasy-drama The Fugitive (1963-67) and the rather hard-hitting (for the time period) war drama Combat (1962-67), and the following season they would take two top ten spots with another unusual hybrid, the camp comic-book-drama Batman (1966-68) -but these experiments did not really involve the crime drama format, which had nearly disappeared from programming in the mid-1960s. However, by 1970 the landscape suddenly changed, and, for the first time since 1950, there were more non-western dramas in the top 20 than there were comedy shows, and nearly all of them were in the top ten. Not only that, but $A B C$, for the first time in its history, had the number-one show in the country, the medical drama Marcus Welby, MD. The landscape seemed ripe for $A B C$ to plant yet another experimental hybrid series, and it would come through Dan Curtis and his made-for-TV movies.

If Dan Curtis was able to shift from his daytime series to primetime film-making, it was because from 1966 onwards all of the networks had a movie-of-the-week program on a certain night of the week, though once again only bigger budgeted CBS (on Fridays) and NBC (on Saturdays) made it into the top 20 programs in Nielsen ratings. That said, ABC made a name for itself by trying to focus more on original programming, with a larger number of made-for-TV movies, rather than rebroadcasts of cinema features, which were proposed as part of its own ABC Movie of the Week (1969-76) slot on Tuesdays (and later Saturdays as well). $A B C$ offered far more sensationalistic films (horror, fantasy, sci-fi) than its competitors, in an attempt to again attract its younger target audience. 
ven Curtis's relative success shaking up the daytime soap opera and especially the critical acclaim of his 1968 TV-film Doctor Jekyll and Mr. Hyde with Jack Palance, ABC was particularly intrigued by his next 1971 film project, a paranormal investigation series something that had never been done before -with a screenplay written by the famed science-fiction writer Richard Matheson, author of the popular 1954 novel I Am Legend and regular writer for The Twilight Zone in the early 60s. Matheson had already provided scripts for ABC's Movie of the Week venue, including his landmark 1971 Duel, one of the first films directed by young Stephen Spielberg and such a huge success for a TV-film that it was later released in cinemas internationally. Their new project was loosely based on an unpublished novel by Jeff Rice entitled The Kolchak Papers, about a tireless journalist pursuing supernatural criminals. For the role of the main character, Karl Kolchak (a character that they would greatly tweak and rewrite from the original), Curtis wanted actor Darren McGavin, an excellent character actor who had not done much high profile work since the 1950s series Mickey Spillane's Mike Hammer (CBS, 1958-60) and Riverboat (NBC, 1959-61) (Dyess-Nugent). Thus, Karl Kolchak, later known as the Night Stalker, was born, and Curtis would provide $\mathrm{ABC}$ with two films that would again help the network briefly get the upper hand over its two rivals.

first film, which aired on January 11,1972) was entitled The Night Stalker -though for the moment the title referred to the villain and not the hero -and, thanks in part to an intense marketing campaign on how scared viewers would be, it garnered the highest ratings of any primetime made-for-TV film of the early seventies, with a 33.2 rating and a 54 share, and at a cost of $\$ 450,000$ (Nielsen; Dyess-Nugent). The new 'paranormal investigation' premise clearly worked, carried in no small part by the remarkable performance of Darren McGavin as Kolchak, a quirky but relentless reporter, in his trademark wrinkled polyester suit and seer-sucker hat, whose investigations into murders of women on the Las Vegas Strip allow him to track down an otherworldly serial killer, a Romanian vampire named Janos Skorzeny. The film also establishes the recurring premise that the government is covering up the supernatural nature of the crimes and doing everything it can to hinder Kolchak's progress, while he also has to deal with his hot-headed but ultimately benevolent editor, Tony Vincenzo (Simon Oakland), who will forever try in vain to get Kolchak to give up on his wild theories but who is always there to bail him out when he gets in trouble with the authorities. Matheson was even given the Mystery Writers of America award for the film, much to Rice's consternation and protest (Dyess-Nugent). ABC naturally asked for a sequel, so Curtis and Matheson created The Night Strangler, which aired a year later on January 16, 1973. This time Kolchak is relocated to Seattle (he has been banned from Las Vegas after the first investigation), and, still working with a frustrated Vincenzo, he investigates a series of murders of exotic dancers, each of whom has had a small dose of blood extracted from her, leading him to the discovery of an evil 144-year-old alchemist who commits these nasty deeds every 21 years to extend his life and youthful demeanor.

In terms of its hybridity, the film series (like the later TV series) relies heavily on devices borrowed from the traditional crime drama -most notably the confrontational relationship between the renegade detective and his loud-mouth, frustrated supervisor (though here it is transposed to a journalist and his editor). You also have a touch of Mickey Spillane (perhaps one of the reasons Curtis chose McGavin) and the trademark use of film-noir voice-over, as Kolchak constantly has a tape-recorder in hand to provide much-needed narration (on- or off-screen) regarding the outcome or cover up of his 
investigation. Most notably, the Kolchak character also borrows heavily from a popular TV investigator who was now on rival NBC's very successful 'wheel show', NBC Sunday Night Mysteries (1971-77) ${ }^{9}$-Columbo (NBC 1968-78; ABC 1989-2003). The similarities to the Kolchak character, as reworked by Curtis and Matheson, are indeed quite striking. Both Kolchak and Lt. Columbo are quirky, unnerving and incredibly tenacious in spite of their harmless appearance. If Columbo has his ratty raincoat and carries a cigar, Kolchak has his crumpled, cheap suit and equally crumpled hat and is always carrying either a tape recorder or camera. And while Columbo drives his vintage Peugeot 403 around L.A., Kolchak cruises the streets of Chicago (in the series version) in an old Mustang convertible. Curtis's team and $\mathrm{ABC}$ were clearly right when they felt that this amalgam of crime drama devices would provide an excellent framework for 'paranormal investigations', for both films garnered very high ratings and made sure that $\mathrm{ABC}$ 's Movie of the Week program, at the number six and number five spot for the 1971-72 and 1972-73 seasons -a record high for a primetime film venue -would finally beat out its rivals, including Columbo and its wheel show. In fact, the first film was such a success that ABC had to come up with a quick 'paranormal investigation' stand-in series in the interim between the two films, in the hopes of capitalizing on the new interest. Thus they created the short-lived series The Sixth Sense that aired from January 15 to December 23 in 1972. The less hip premise -that of a smooth 'parapsychologist detective' (Gary Collins) and his pretty assistant (Catherine Ferrar), who investigate inexplicable psychic phenomenon sadly never got off the ground, mostly because the series was scheduled on Saturdays at 10:00 pm opposite CBS's unbeatable Mission: Impossible. Completely forgotten today, the series was in fact cancelled once Curtis and Matheson's second film was ready to be aired.

41 With the success of the two Kolchak films, Matheson had prepared a third film script that was to be entitled The Night Killers (this time Kolchak was to stumble onto aliens who were colonizing Hawaii, in their first step toward world domination, by replacing influential humans with android doubles). Instead, $\mathrm{ABC}$ insisted the Kolchak concept be converted to a weekly TV series format, an idea that both Matheson and especially Curtis disagreed with (Dyess-Nugent). First of all, Curtis had just made a 1973 TV film on a similar premise, The Norliss Tapes -which also dealt with an investigation into modern-day vampires and which he thought would more easily adapt to a weekly show (Thompson 11). Secondly, Curtis thought the monster-of-the-week premise that $A B C$ was pitching to them was a "bad idea", as did McGavin (Dyess-Nugent). Though McGavin eventually gave into the idea, Curtis and Matheson passed on it to stay in film-making. Even Rice refused to give $\mathrm{ABC}$ the rights for his novel (that he was only now publishing in light of the success of Matheson and Curtis's films), and only accepted the offer when $A B C$ agreed to give him (rather than Curtis and Matheson), the coveted 'created by...' title card in the opening credits (Dyess-Nugent).

ABC seemed to have everything they needed to make their new hybrid TV series, Kolchak: The Night Stalker (1974-75), a success, and given the hype around the films, one-time rival Universal signed on to produce the show. However, without Curtis and Matheson at the helm, the show was left in the hands of ABC executives who asked young TV writers to submit ideas and scripts for individual episodes, each with a different monster or alien of their choosing. Though some of the writers were quite talented -including future stars like Robert Zemekis and Bob Gale (who would later make the Back to the Future films in the 1980s) and David Chase [future showrunner for The Sopranos (HBO, 1999-2007)] -the show thus had no semblance of a show-runner and left no possibilities for story-arcs longer 
than one episode -something that Darren McGavin would constantly complain about (Dyess-Nugent) and that would never allow the long-term character development that Dark Shadows had benefited from ${ }^{10}$. This unfortunate 'monster-of the-week' set-up, compounded with the smaller budget allowed for a single TV episode, when compared to the feature films Curtis had made, meant once again low production values and cheap special effects, particularly in terms of the weekly guest-creature. These paranormal perpetrators included vampires, werewolves and witches, of course, but also mummies, zombies, a lizard-man, a succubus, aliens, android replicants (using an idea from Matheson's lost script), Jack the Ripper, an immortal Helen of Troy, legendary creatures from Native American, Creole and Hindu folklore, and -undoubtedly the poorest in terms of special effects -a headless motorcyclist (See Plate 6). To make matters even worse, ABC scheduled the series on Fridays at 10:00 pm (surely thinking teens and young adults could stay up late on Fridays to watch, and thinking that it would be too 'scary' for an earlier slot), but this was a grave miscalculation, as Fridays and Saturdays were not nights when teens and young adults were at home in front of their TV. Late Friday nights became a graveyard shift in ratings.

\section{Plate 6: Kolchak and his Monster-of-the-Week}

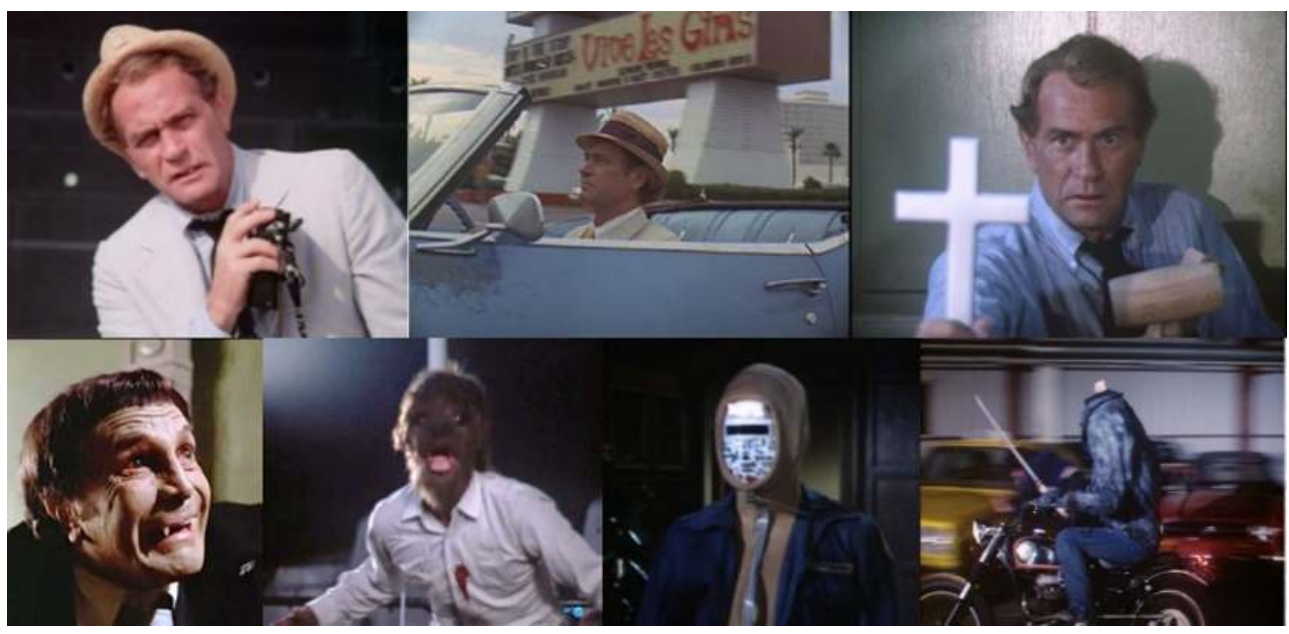

A few screen grabs of Darren McGavin as Kolchak in the 1972 film and the 1974-75 series, along with a small sampling of some of his low-budget nemeses: vampire Janos Skorzeny (1972 film), the cruiseship werewolf (01.05), Mr. R.I.N.G. the android (01.12) and headless motorcycle rider (01.15).

In the end, the series lasted less than one full season, and it was McGavin himself who pulled the plug in 1975. Before the last episodes aired, he was already complaining to reporters about the lack of coherence in the scripts, the incompetent corporate management and the fact that he had to step in himself to do production work and lastminute rewrites. He even quite openly insulted $\mathrm{ABC}$ executives and the "huge pool of mediocrity" they had created, declaring to a reporter, "I hope they cancel this show as quickly as they can and get it out of their corporate, pinheaded minds!" (Dyess-Nugent). A few weeks later, as ratings were dwindling fast, $A B C$ cancelled the show with several episodes left to film, though some of those lost scripts would later be transposed into comic books in 2002 for nostalgic fans of the series.

Once again, $A B C$ had come up with a monster-meets-other-subgenre hybrid, and once again, in terms of the goal of toppling its rivals in the ratings, the plan had failed, apparently even more miserably in the case of the 'paranormal crime series' than in the 
previous Gothic-monster-soap and the over-the-top Monstercom. Yet The Night Stalker experiment, with only 20 episodes and two films, would be as undead an entity as its trademark vampires and zombies, for the series quickly became a cult favorite and influenced an entire generation -not only of avid viewers who were hooked on the new concept, but also of future TV writers and showrunners, including Chris Carter. In the 1990s, when Carter's X-Files became one of the most popular dramas on television, many nostalgic fans of Kolchak made the connection between the two series. Although Kolchak had been a reporter and not an FBI agent, he nonetheless had to investigate paranormal activities, was often the only one to believe in the supernatural dimension of the crimes, and did so while fighting clandestine government agents and massive cover-ups -and when Kolchak recorded his findings he consistently told viewer that the truth was being kept from them (i.e., "The truth is out there", as reads the X-Files tagline). Moreover, Carter himself would admit the influence, going so far as to say that the formula for his $X$ Files was $30 \%$ Kolchak, $10 \%$ Twilight Zone and $60 \%$ original ideas (Crow) -though one might think there may have also been at least $5 \%$ The Sixth Sense -that now- forgotten series that aired between the two Kolchak films and that staged a somewhat flirtatious male-female duo as the lead investigators. In fact, Carter would quite openly pay homage to the 1970s Kolchak source by having an aging Darren McGavin appear as a guest star on three episodes of the X-Files that aired in 1998 and 1999: 'Travelers' (05.15), 'Agua Mala' (06.13) and 'The Unnatural' (06.19). McGavin refused to play the role of Kolchak again, but honored the invitation and was written in as Arthur Dales, a cranky and aging former agent who was in fact hailed as the 'founder of the X-Files unit'. Even in the more recent reboot of the X-Files (2016), the third episode, "Mulder and Scully Meet the WereMonster", is an episode in which Mulder is chasing a lizard-man (a premise that calls back to the old series) who when in human form dresses exactly like the old Kolchak character (10.3). Also, in 2005, ABC felt that technology and production values for such programs had sufficiently evolved for them to try to bring in their own reboot of the original Night Stalker (The network only had rights to the two films, as Universal maintained rights to the series; thus they had to base the reboot exclusively on characters found in Curtis's films). The new series takes place in a modern-day newsroom in Los Angeles, with actor Stuart Townsend playing a far more serious and less quirky Carl Kolchak. That said, ABC tried to pay tribute to the original series as well, by having Darren McGavin's original character written into the pilot in a most unusual way -for the scene showing McGavin (as he looked in 1972) packing his briefcase in a 2005 newsroom is a digitally inserted sequence from the original film (though while he had been packing a wooden stake in the original, here he is putting papers away). Yet once again, $\mathrm{ABC}$, apparently the victim of some ancient curse, would again fail in the ratings, and the 2005 reboot would be cancelled after only six episodes (See Plate 7). 


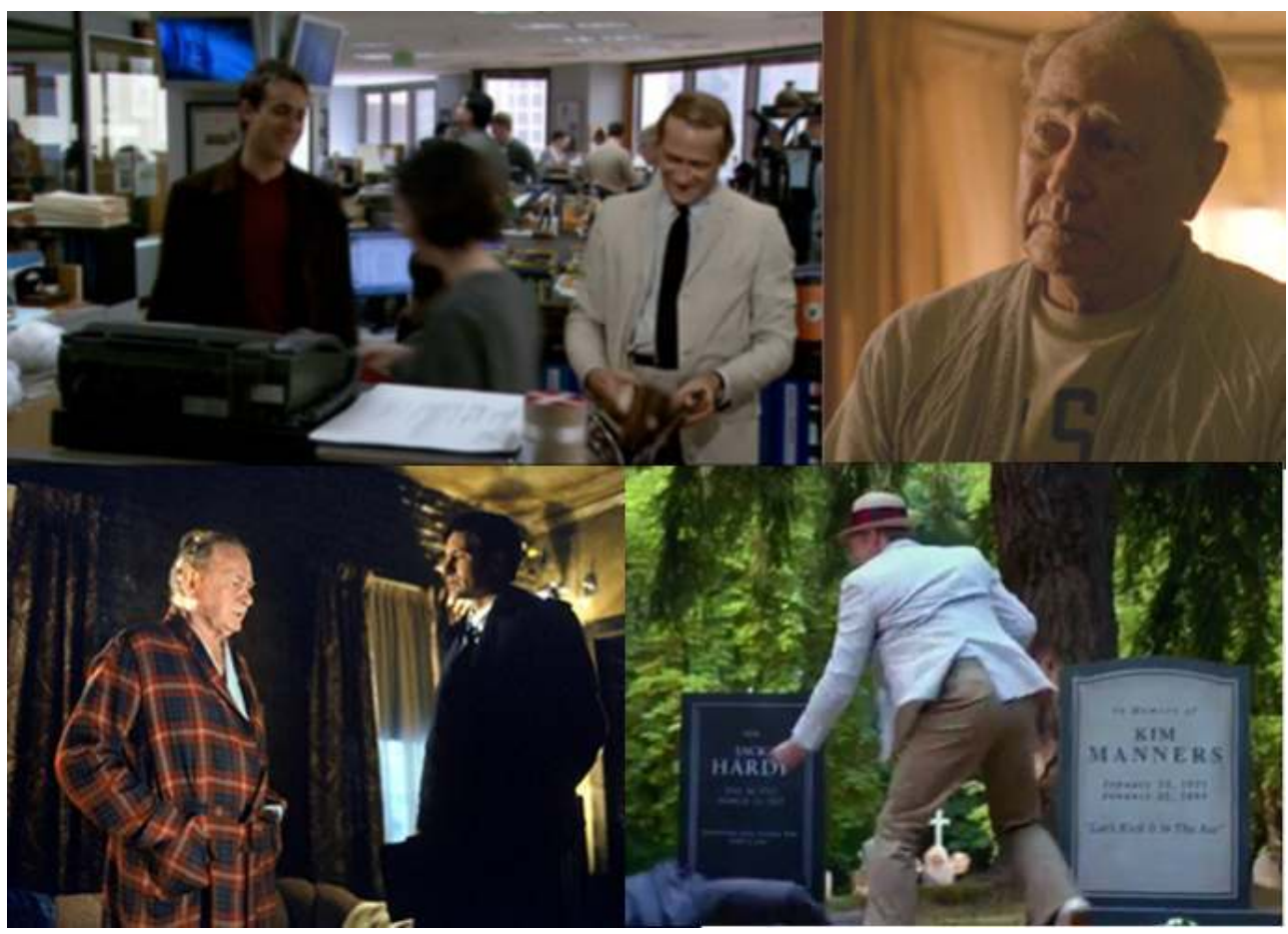

(top left) Darren McGavin's character is digitally inserted into the pilot for the Night Stalker reboot in 2005; (top right and bottom left) McGavin has a cameo role on the first run of the $X$-Files as retired FBI agent Arthur Dales, the "founder of the X-Files" (06.19; 05.15); (bottom right) though McGavin died in 2006, the 2016 reboot includes an indisputable Kolchak lookalike as a shape-shifting monster (10.03).

Thus, from the early sixties to the mid-seventies, ABC's attempts at wooing audiences with counterprogramming, fueled by a bitter rivalry with top-seeded CBS, produced these three unexpected hybrid series subgenres, all of which claimed to somehow combine fantastic or especially Gothic literature with a separate tried-and-true TV format (the sitcom, the soap opera and the crime drama). At first view, one might conclude that these endeavors, as bold as they might have been, were failures on many levels. In the end, one has a hard time considering them to be true adaptations of literary works, and at times even the term 'loose adaptations' might be an understatement, as these programs were often adaptations of other adaptations (cartoon creations inspired by Gothic literature, Universal's popular movie monsters of the 1930s, loosely inspired and low-budget 'monsters of the week') -merely light shadows of shadows, one might say. Only Dark Shadows borrowed directly from landmark works of literature, but the hodgepodge of overlapping and loosely packaged Gothic characters and story-lines that resulted could hardly be called high-brow. In all three cases, in the end, the 'borrowing' of Gothic literature was done in very broad strokes.

To make matters worse, if the networks' main goal was to find a new hybrid that would trigger top-notch ratings, all three experiments could be said to have failed. In spite of the great hype over the raucous monster-sitcom battle that brewed in the early sixties, neither The Munsters nor The Addams Family ever made it into the top twenty shows and were cancelled after their second season. The paranormal crime drama was even worse, 
for the show's own star pulled the plug before the end of the first season, and ratings were so low that $\mathrm{ABC}$ did not even fight to get him to finish his contract. In the end, only ABC's Dark Shadows ever made it into the top twenty, peaking at number eleven and winning its time slot against its rival networks' game shows and talk shows -though its ratings were far lower than the other networks' more conventional afternoon soap operas that still held all the top spots. Indeed, with the exception of the first Night Stalker film and its hype as 'horror for TV', ABC did not even come close to their goal of toppling ratings-leader CBS with these experiments in 'counter-programming', for such risktaking simply had not immediately paid off in terms of what we might call 'the three R's' of network television: ratings, reviews or ad revenues.

In the end, the Kolchak series would be one of the last experimental projects of the period to be offered by $A B C$, as it was just after show's cancellation that $A B C$ and its head of programming Fred Silverman would completely change the network's once radical and upstart philosophy, giving up on its trademark 'counterprogramming' and going for far more conventional programs, soon taking a majority of the top ten spots with more soothing family favorites like Happy Days (1974-84) and its spin-offs Laverne \& Shirley (1976-83) and Mork \& Mindy (1978-82), or programs like Three's Company (1977-84) or Charlie's Angels (1977-84) for the slightly hipper demographic, or Taxi (1978-82) and Barney Miller (1975-82) for middle-aged men, Dynasty (1981-89) for middle-aged women, and Love Boat (1977-86) for the much older crowd. It was thus by giving up on the radical experiments that had brought the likes of The Addams Family, Dark Shadows and The Night Stalker and going for far more conventional fare that $\mathrm{ABC}$ had finally gotten its wish, overtaking CBS as the number one network from 1977 until the mid-1980s.

However, it would be wrong to think of these different hybrid series as failures. As mentioned throughout this study, these programs would be kept alive through syndication and through an ever-growing fandom that spanned generations of TV viewers in the U.S. Perhaps these experiments were 'before their time', for it seems that later generations more readily took to the countercultural dimensions of the programs and made them the cult-favorites that they are today, generating perpetual fan clubs, perennial fan-conventions (such as Dark-con for Dark Shadows fans) and innumerable fanzines on the internet to this day. To try to capitalize on this eternal fandom, networks, as we have seen, have attempted modern reboots of all of the hybrid shows under study yet not one of these reboots has lasted more than a few episodes, for it seems that updating the premises or improving the production values just denatures the beloved original work that even younger generations still hold dear.

However, if modern reboots have all failed, there are still traces of these landmark experiments all around us, proving the true merit and avant-garde nature of these once low-rated hybrids. The Monstercom, for example, has evolved and multiplied from the early days of The Munsters and The Addams Family, is now a staple of children's networks like Nickelodeon and can be found both as live-action sitcoms [e.g., Sabrina the Teenage Witch (ABC/WB - 1996-2003), Teen Wolf (MTV, since 2011), and Nickelodeon's The Haunted Hathaways (2013-15), The Thundermans (2013-present) and Every Witch Way (2014-15)] and as animated series such as Zombie Hotel (BBC/France3), Hairy Scary (France3/RTL) or the incredibly popular Monster High (Nickelodeon, since 2010) and its web series lookalike Ever-After High (since 2014). It seems that today's children are even more taken by the subgenre's misfit-based metaphors on diversity, acceptance and empowerment. 
50 As for Dan Curtis's two key contributions, the legacy of Dark Shadows and of The Night Stalker has given rise to far more adult fare. The Gothic monster serial launched by Dark Shadows has now come of age, benefits from better production values and special effects, and is extremely popular. This legacy includes Buffy the Vampire Slayer (WB/ UPN, 1997-2003) and its spin-off Angel (1999-2004), True Blood (HBO, 2008-14), Haven (ScyFy, 2010-present) and especially Showtime's recent hit Penny Dreadful (2014-16), which similarly borrows its characters and plots from landmark works of Gothic literature and which truly shows us what Dark Shadows could have been had it benefited from a blockbuster budget and today's permissiveness in terms of television sex and violence. One could even argue that the Twilight film series owes a great deal to Dark Shadows' Barnabas and Quentin Collins. As for Kolchak's legacy, Chris Carter would give us both his admitted tribute to the failed series in The X-Files and a second homage in its sister show Millennium (FOX 1996-99). Since then, the supernatural investigation series has multiplied to include programs like Supernatural (WB/CB 2005-present), Grimm (NBC, 2011-present), Constantine (NBC, 2014-15), Lucifer (FOX, since 2016) and J.J. Abrams's Fringe (FOX 2008-13) -the last of which combines paranormal investigation (as in Kolchak) with the added dimension of parallel universes (as in Dark Shadows). It is interesting to note that these modern paranormal investigative series all benefit from longer story arcs and enhanced development of characters (be they human or creature) over time-the very thing that Curtis and McGavin felt had hindered the success of their Night Stalker series in the 1970s.

Thus, three supposedly 'failed' experiments in the sixties and early seventies -the Monstercom, the Gothic monster soap opera and the paranormal crime drama -were far more ground-breaking than they may have seemed at the time. They may have been 'light shadows' in terms of their low-brow borrowing of Gothic literature and quaintly inexpensive production values, but they have cast a decidedly long shadow and undeniable influence over today's programming.

\section{BIBLIOGRAPHY}

BENSHOFF Harry M., Dark Shadows, Detroit, Wayne UP, 2011.

BENSHOFF Harry M., "Resurrection of the Vampire and the Creation of Alternate Life: An Introduction to Dark Shadows Fan Culture" The Spectator 13:3 (July 1993): 50-61.

Biography: The Munsters, America's First Family of Fright (Television production), 8 July 2003. Dir. Rick Hull; written by Jerry Decker. DVD 2006.

CLARK Melody, Kathleen RESCH and Mary ROBIN, “The Dark Shadows History,” in Katheryn LeighScott (ed.) The Dark Shadows Companion: $25^{\text {th }}$ Anniversary Collection, Los Angeles and London, Pomegranate Press, 1990, 42-173.

CROW Steve, X-Files vs. The Night Stalker, October 12, 2007. Rpt. in It Could Happen Here, http:// web.archive.org/web/20071012223844/http://www.geocities.com/Area51/Stargate/4991/ kolchak/klchk10.htm, last consulted March 2015. 
CURTIS Dan (dir.), Dark Shadows DVD box set (vol. 16). Jan 25, 2005.

DE CARLo Yvonne and Doug Warren, Yvonne, An Autobiography, New York, St. Martin's Press, 1987.

DYESS-NUGENT Phil, "How Kolchak: The Night Stalker Developed as an Early Model for TV Horror," TV Club. Feb. 10, 2014. http://www.avclub.com/article/how-kolchak-the-night-stalkerdeveloped-an-early-m-201079, last consulted September 2017.

EDGERTON Gary R, The Columbia History of American Television, New York, Columbia University Press, 2007.

EDWARDS Ted, X-Files Confidential, Little, Brown and Company, 1996.

Fox George. "Can a 172-year-old vampire find love and happiness in a typical New England town?" Saturday Evening Post 30 Nov. 1968: 40-41, 80-81.

FRENCH Philip, I Found It at the Movies: Reflections of a Cinephile. Manchester, UK, Caranet Press Ltd., 2001.

GARCIA Robert T., “A Retrospect of the 'Original' Addams Family." Cinefantastique, 22, 3: 40-46.

GOLDENSON Leonard H. and Marvin J. WOLF. Beating the Odds: The Untold Story behind the Rise of ABC, New York: Charles Scribner's Sons, 1991.

GLUT Donald F., The Frankenstein Archive: Essays on the Monster, the Myth, the Movies, and More, Jefferson, NC, McFarland and Co., 2002

намАмото Darrell Y., Nervous Laughter: Television Situation Comedy and Liberal ,Democratic Ideology, New York, Praeger Press, 1989.

HAMRICK Craig, and R. J. Jamison, Barnabas \& Company: The Cast of the TV Classic Dark Shadows, Bloomington, IL, iUniverse, 2012.

JOHNSON Catherine, Telefantasy, London, BFI, 2008.

JONES Gerard, “Honey, I'm Home” -Sitcoms: Selling the American Dream, New York, St. Martin's Press, 1992.

JOWETT Lorna and Stacey ABBOTT, TV Horror: Investigating the Dark Side of the Small Screen. New York, I.B. Taurus \& Co. Ltd., 2013.

KELLOW Brian, The Bennets: An Acting Family, Lexington, KY, UP of Kentucky, 2004.

KNIPfEL Jim, "Kolchak: The Night Stalker - The Genealogy of a Classic Horror TV Series," Den of Geek, http://www.denofgeek.us/tags/kolchak-the-night-stalker-0, last consulted October 5, 2015. LEIGH-SCOTT Kathryn, and Jim PIERSON (ed.), The Dark Shadows Almanac, New York, Pomegranate Press, 1995.

LEIGH-SCOTT Kathryn, Dark Shadows: Return to Collinwood, New York, Pomegranate Press, 2012. LOWRY Brian, The Truth is Out There: The Official Guide to the X-Files, New York, Harper Prism, 1996. MARC David, Comic Visions: Television Comedy and American Culture, Oxford, Blackwell Publishers, 1989.

"McHale's Navy", Archives of American Television, http://www.emmytvlegends.org/interviews/ shows/mchales-navy, last consulted May 15, 2014.

MESSENGER-DAVIS Marie, 'Dear BBC': Children, Television Storytelling and the Public, Cambridge, Cambridge University Press, 2001. 164-65. 
MOSELEY Rachel, "Glamourous Witchcraft: Gender and Magic in Teen Film and Television," Screen 43.4. $403-22$.

"Nielsen Ratings - U.S. Television," Classic TV Archive, http://ctva.biz/US/TV-Ratings/ CTVA_NielsenRatings.htm, last consulted March-April 2015.

OBIAS Rudie, “Twelve Unaired Pilots of Popular TV Shows," Mental_Floss, http://mentalfloss.com/ article/62519/12-unaired-pilots-popular-tv-shows, last consulted 10 March 2016.

ROSSEN Jake. "Fourteen Dark Shadows Facts with Bite” Mental_Floss, mentalfloss.com/ article/69738/14-dark-shadows-facts-bite, last consulted September 2017.

SMITH, Dick. "Dark Shadows, Television Series - 1967" \& "Dick's Life and Work", Dick Smith MakeUp, www.dicksmithmake-up.com/dicks-life-and-work/life-and-work, last consulted September 2017.

SPIGEL, Lynn and Michael CURTIN, The Revolution Wasn't Televised: Sixties Television and Social Conflict, New York, Routeledge, 1997.

THOMPSON, Jeff, The Television Horrors of Dan Curtis: Dark Shadows, The Night Stalker and Other Productions, 1966-2006, Jefferson, NC, McFarland \& Co., 2009.

TUDOR, Anthony. “Unruly Body, Unquiet Minds” Body \& Society 1.1 (March 1995) 25-41.

WHEATLEY, Helen, Gothic Television, Manchester, Manchester University Press, 2006.

\section{NOTES}

1. For more on the rise and development of American military sitcoms, see my article "'War, What Is It Good For? Laughter and Ratings': Sgt. Bilko, $M^{*} A^{*} S^{*} H$ \& the Heyday of U.S. Military Sitcoms (1955-75)", TV/Séries 10, Guerres en Séries II (Fall 2016). https://tvseries.revues.org/621.

2. Throughout this study, all references to specific audience ratings for programs of the period and the yearly Top 20 rankings of American television programs, better known as Nielsen Ratings, are based on the official statistics as reprinted in the Classic TV Archive: http://ctva.biz/ US/TV-Ratings/CTVA_NielsenRatings.htm

3. Even though The Addams Family series was decidedly more highbrow than its CBS rival, it was not highbrow enough for it not be belittled by the publisher of the original cartoons, The New Yorker. In fact, William Shawn, the editor of the literary magazine, was so upset at the very idea that the cartoon would be adapted to a television sitcom that he banned The New Yorker from ever again publishing a cartoon by Charles Addams. Indeed, it was only after Shawn retired from the magazine in 1987 that Addams, a year before his death, was again allowed to provide cartoons with his now famous 'family' characters (French).

4. Fans of The Munsters often mistakenly claim that the 1964 program was the first sitcom to show a married couple who sleep in a double bed rather than less suggestive twin beds. However, it was in fact the fourth sitcom to do so. The first was in fact the very first sitcom ever aired on American television, Mary Kay \& Johnny (DuMont Network, 1947-50). As the two leading actors were married in real life, the double bed was not seen as problematic, and this would also be the case for the first two seasons of I Love Lucy (CBS, 1951-57), though when the married stars had a child (both in real life and on the sitcom) in 1953, the double bed was no longer permitted for the connection viewers might make between pregnancy and the double bed. Finally, just a few weeks before The Munsters bedroom was seen on television, $\mathrm{ABC}$ had already displayed a double bed for Samantha and Darren Stevens on Bewitched (1964-72). So it seems that before the 1970s, a married 
couple portrayed on a television sitcom could only have a double bed if their actors were married in real life or if at least one of the spouses was not human.

5. Helen Wheatley, in her landmark work Gothic Television of 2006, discusses many episodes of The Addams Family that seem to both advance and hinder the cause for more progressive views of women in the early sixties (141-45), a point reiterated in Lorna Jowett and Stacey Abbott's 2013 $T V$ Horror (23-25). Other critics have dealt with such questionable advances in the feminist cause as regards the Magicoms of the 1960s in general, such as or Laura Spigel's article "White Flight" in her 1997 collection The Revolution Wasn't Televised (47-71) or Rachel Moseley's 2002 “Glamorous Witchcraft: Gender and Magic in Teen Film and Television" (403-22).

6. For a detailed account of science fiction and fantastic TV series of the 1950s and 1960s, see Catherine Johnson's Telefantasy (London: BFI, 2008), a work that though focusing more on science fiction and fantasy dramas like Star Trek or The Prisoner also deals with the development of fantastic and Gothic series by the networks, with their value as experimentations in form and visual style, and with their subversive nature in terms of challenging domestic as well as televisual norms.

7. It would only be throughout the 1970s that nearly all afternoon soap operas would expand to the one-hour format that still exists today, and the programs were broadcast live from New York until they progressively made the switch to L.A. and video-tape in the late sixties and early seventies. Also note that the fact that these live New York teleplays allowed producers easy access to both stage actors and theatres in which to shoot the programs. In the very early years of television, the same process had been used to broadcast teleplay adaptations of literary works during primetime, an attempt to ensure that culture would not be forgotten in the shift from radio to television. In the 1950-51 season, six weekly theatre programs were in the top 20 programs, two of which were in the top five. However, this early staple was soon edged out of the primetime schedule by the growing popularity of the sitcom, variety shows, westerns and crime dramas -and so the afternoon soap opera began to assume the bulk of teleplay production, with such primetime drama showcases dwindling down to nearly nothing by 1957.

8. A more detailed list of the literary subtexts and related story-lines discussed in this and the following paragraph, along with several others not discussed here, can be found in Kathryn Leigh Scott's The Dark Shadows Almanac. Ed. Jim Piersons. London: Pomegranate Press, 1995. 134-140.

9. A wheel-show is an anthology film program that rotates a fixed number of serial films every week, and is thus a cross-over between the concepts of the made-for-TV movie and the TV drama series. In this case, NBC Sunday Night Mysteries had four investigative films in rotation once a week: McCloud (Dennis Weaver), Columbo (Peter Falk), McMillan \& Wife (Rock Hudson) and Hec Ramsey (Richard Boone). The program averaged 15 million households and was consistently in the top 20 in ratings, peaking at number 6 in the 1972-73 season (Nielsen).

10. Jowett and Abbott, in their recent study TV Horror, compare and contrast the two hybrid series from Curtis, Kolchak and Dark Shadows, in terms of their seriality and their use of gothic story-telling devices. As they point out, the long seriality of the earlier soap opera allowed for otherworldly creatures to become regular characters and develop over time, whereas in Kolchak they were merely grunting two-dimensional monsters to be killed off post haste $(49,205)$. It could thus be said that the episodic set-up undermined Kolchak's horror bona fides, as we know the investigator will someone vanquish the monster-of-the-week by the end of the show, making it the epitome of what Anthony Tudor called "secure horror," in which, after the disruption caused by some "disturbing influence" (monster, serial killer, ghost, etc.), "order (of some kind) is restored" (Tudor 34). Thus Dark Shadows' more intimate format, its never-ending story arcs and "lack of narrative resolution", and its slow and steady development of its creature-characters and their resulting moral ambiguity, all point to the earlier soap opera being a better fit in terms of Gothic hybridity for television (47). At the same time, Jowett and Abbott argue, Kolchak's more realistic filming techniques, which were more in line with neo-noir crime dramas of the 1970s 
(location shooting even at night, grainy visuals, hand-held camera work ,etc.), corresponded to the show's main premise -that the real world around us is in fact fraught with hidden monsters and government cover-ups (45).

\section{ABSTRACTS}

If today's television landscape is ripe with Gothic or supernatural dramas (True Blood, Penny Dreadful, Supernatural), paranormal crime dramas (X-Files, Grimm) and, on children's networks, animated or live-action sitcoms about monsters and ghouls trying to fit in at home or at school ( Monster High, Every Witch Way), all of this programming can be traced back to its humble origins in the 1960s and 1970s. This study will focus on the creation of three different types of hybrid series that were aired during this early period and each of which attempted to combine supernatural characters and story-lines borrowed from traditional Gothic literature (and later from science fiction) with a different standard and rather conventional TV format. In the early 1960s, The Munsters on CBS and The Addams Family on $\mathrm{ABC}$ brought Gothic monsters and otherworldly misfits into the family sitcom. This was immediately followed by two successive contributions from TV producer-director Dan Curtis for ABC -first in the late sixties with Dark Shadows, the 'Gothic soap opera' that took the melodramatic afternoon serial format and spiced it up with dozens of overlapping subtexts on classic vampires, werewolves and witches, and then in the early seventies with two TV films that resulted in the first 'paranormal investigation series', Kolchak: The Night Stalker. In addition to analyzing the hybrid nature of these experimental programs and their rather light borrowing of literary icons in terms of adaptation, this study will also focus heavily on the context and television landscape into which these two-headed hybrids were born. To understand their countercultural value, one must first understand the type of programming that was dominant at the time, as well as the battle for dominance in those allimportant Nielsen ratings that would drive certain networks to bolder experimentation. All three of these hybrid series were indeed the spoils of the Network Wars, and all involved third-place ABC's attempt to overturn CBS's unshakeable dominance through counter-programming and the targeting of new demographics. Finally, this article will also focus on the inherent paradox shared by these early 'monster-mashes', for at the time most of these series failed in terms of expected audience numbers, and all but Dark Shadows were canceled after one or two seasons. Yet, these series -though often camp if not unintentionally burlesque and with often laughably low production values by today's standards -have still consistently grown in popularity over time, thanks to syndication, later reboots on TV and as feature films -making these initial hybrids and their off-the-wall characters cult icons today and leading to scores of current programs that readily admit to the significant influence of these early, low-budget experiments.

Les séries qui reposent sur le gothique et le surnaturel (True Blood, Penny Dreadful, Supernatural), sur les affaires criminelles paranormales (X-Files, Grimm) et sur les monstres et autres goules ( Monster High, Every Witch Way) sont nombreuses dans le paysage audiovisuel actuel. Or, il faut remonter aux années 1960 et 1970 pour trouver l'origine de cet engouement. Il s'agit ici d'étudier la création de trois formes de séries hybrides qui ont été diffusées à l'époque et qui combinaient personnages surnaturels et intrigues empruntées à la littérature gothique (et, plus tard, à la science-fiction), intrigues qui ont été adaptées au format télévisuel. Au début des années 1960, The Munsters (CBS) et The Addams Family ( $\mathrm{ABC}$ ) mêlent monstres gothiques et sitcom familiale. 
S'ensuivent deux programmes du producteur-réalisateur Dan Curtis sur ABC : Dark Shadows, sorte de soap gothique, qui inscrit des références aux vampires, loups-garous et autres sorcières au sein du mélodrame sériel de l'après-midi ; puis deux téléfilms au début des années 1970 qui donnent naissance à la première série policière paranormale, Kolchak: The Night Stalker. Au-delà de l'analyse de l'hybridité de ces séries expérimentales et de leurs emprunts littéraires, il s'agit aussi de se pencher sur le contexte télévisuel. Pour appréhender leur portée contre-culturelle, il est, en effet, nécessaire de comprendre les pratiques de programmation de l'époque, ainsi que les luttes d'audience qui ont poussé certains networks à lancer des programmes de plus en plus audacieux. Toutes ces séries hybrides ont été le résultat d'une guerre des chaînes et sont nées de la tentative d'ABC de passer de la troisième place à la première, en détrônant $C B S$ et en ciblant un nouveau public. Cet article conclut sur le paradoxe que partagent ces premiers mélanges monstrueux : ils ont tous été, en effet, des échecs en termes de taux d'audience. Seule la série Dark Shadows n'a pas été annulée après une ou deux saisons. Cependant, ces séries auxquelles un petit budget confère un aspect camp à la limite du burlesque, ont progressivement acquis une popularité grâce aux rediffusions, aux reboots et aux adaptations cinématographiques. Elles sont devenues des objets cultes dont l'influence transparaît encore dans les programmes d'aujourd'hui.

\section{INDEX}

Mots-clés: adaptation, Dark Shadows, Munsters, Addams Family, Kolchak: The Night Stalker, network wars

Keywords: adaptation, Dark Shadows, Munsters, Addams Family, Kolchak: The Night Stalker, network wars

\section{AUTHOR}

\section{DENNIS TREDY}

Dennis Tredy is an associate professor of American Literature at the Université de Paris IIISorbonne Nouvelle. He is co-founder of the ESJS (European Society of Jamesian Studies) and is the main volume editor of two recent books on Henry James: Henry James and the Poetics of Duplicity (2013) and Henry James's Europe: Heritage and Transfer (2011). In addition to his publications on James and on other American novelists (including Steinbeck, Nabokov and Capote), Dennis Tredy has published studies of film adaptations of the works of Henry James, as well as a recently published study of the film adaptations of the stories of Edgar Allan Poe ["From The House of Usher to The Louse of Usher: Expansion Techniques in Film Adaptations of the Works of Edgar Allan Poe in the 1960's and Today," Interfaces (Expanding Adaptations), n³4, 2013]. His recent work on TV series has centered on the representation of American culture, diversity and counter-culture in the 1960's and 1970's.

Dennis Tredy est maître de conférences en littérature américaine à l'Université de Paris IIISorbonne Nouvelle. Il est co-fondateur de la Société européenne d'études jamesiennes, et a récemment édité deux ouvrages sur l'auteur: Henry James: Henry James and the Poetics of Duplicity (2013) et Henry James's Europe: Heritage and Transfer (2011). En plus de ses travaux sur James et d'autres romanciers américains (Steinbeck, Nabokov, Capote), Dennis Fredy a publié des analyses des adaptations filmiques des oeuvres de Henry James, ainsi qu'une étude des adaptations d'Edgar Allan Poe ["From The House of Usher to The Louse of Usher: Expansion Techniques in Film 
Adaptations of the Works of Edgar Allan Poe in the 1960's and Today," Interfaces (Expanding Adaptations), n³4, 2013]. Ses travaux récents sur les séries télévisées portent sur la représentation de la culture américaine, la diversité et la contre-culture des années 60 et 70. 